\title{
Cone Calorimeter Rate of Heat \\ Release Measurements for Upholstered Composites of Polyurethane Foams
}

Kay M. Villa

Vytenis Babrauskas

U.S. DEPARTMENT OF COMMERCE National Institute of Standards and Tochnology Building \& Fire Research Laboratory Gaithersburg, MD 20899 



\section{Cone Calorimeter \\ Rate of Heat \\ Release Measurements \\ for Upholstered \\ Composites of \\ Polyurethane Foams}

Kay M. Villa

Vytenis Babrauskas

U.S. DEPARTMENT OF COMMERCE National Institute of Standards and Tochnology

Building \& Fire Research Laboratory Gaithersburg, MD 20899

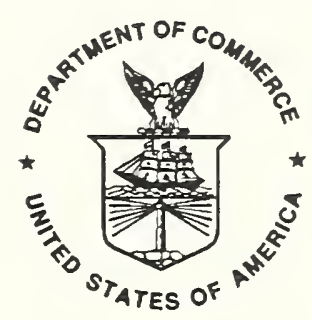

U.S. DEPARTMENT OF COMMERCE Robert A. Mosbacher, Secretary MATONAL INSTIUUTE OF STANDARDS AND TECHNOLOGY

John W. Lyons, Director 

List of Tables $\ldots \ldots \ldots \ldots \ldots \ldots \ldots \ldots \ldots \ldots \ldots \ldots \ldots \ldots \ldots \ldots \ldots \ldots \ldots \ldots \ldots$

List of Figures $\ldots \ldots \ldots \ldots \ldots \ldots \ldots \ldots \ldots \ldots \ldots \ldots \ldots \ldots \ldots \ldots \ldots \ldots \ldots$

Abstract $\ldots \ldots \ldots \ldots \ldots \ldots \ldots \ldots \ldots \ldots \ldots \ldots \ldots \ldots \ldots \ldots \ldots \ldots \ldots \ldots \ldots$

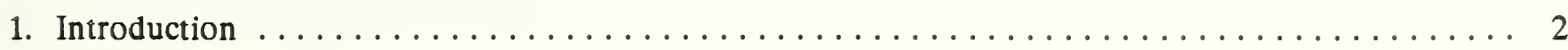

2. Methods ......................................... 3

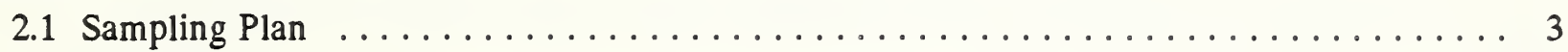

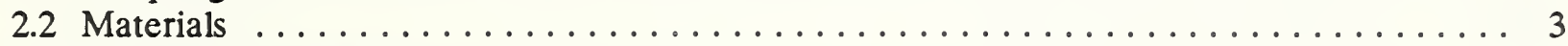

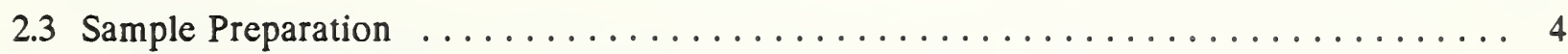

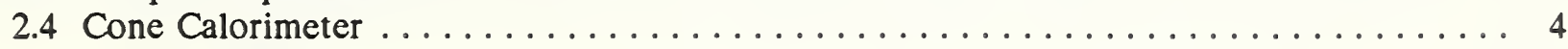

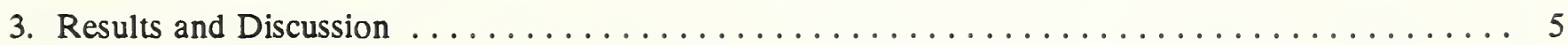

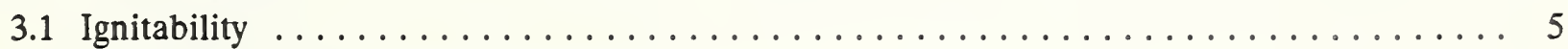

3.2 Mass Loss and Total Heat Released ........................... 6

3.3 Rate of Heat Release ... . . . . . . . . . . . . . . . . . . . . . . 7

3.4 Yields of Other Products of Combustion .................... 9

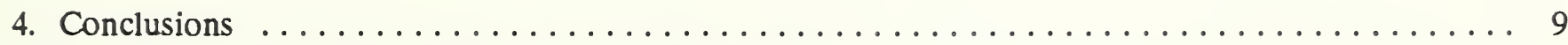

5. References $\ldots \ldots \ldots \ldots \ldots \ldots \ldots \ldots \ldots \ldots \ldots \ldots \ldots \ldots \ldots \ldots \ldots \ldots \ldots \ldots \ldots$ 
Table 1. Time to Ignition 13

Table 2. Percent Mass Loss 14

Table 3. Total Heat Release 15

Table 4. Effective Heat of Combustion 16

Table 5. 180 Second Interval Rate of Heat Release . . . . . . . . . . . . . . . . . . 17

Table 6. Peak Rate of Heat Release $\ldots \ldots \ldots \ldots \ldots \ldots \ldots \ldots \ldots \ldots \ldots \ldots \ldots \ldots \ldots \ldots$

Table 7. 120 Second Interval Rate of Heat Release . . . . . . . . . . . . . . . . . . . . 19

Table 8. 15 Second Interval Rate of Heat Release . . . . . . . . . . . . . . . . . . 20

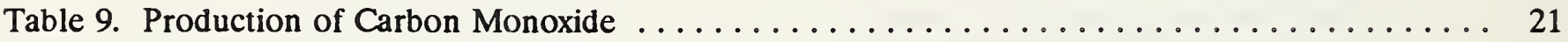

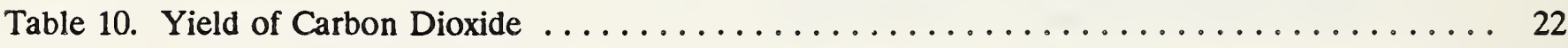

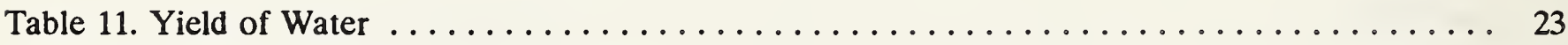

Table 12. Yield of Total Unburned Hydrocarbons ....................... 24

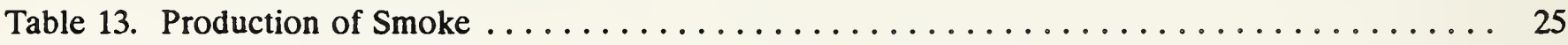




\section{List of Figures}

Page

Figure $1 . \quad$ Schematic Diagram of the Cone Calorimeter $\ldots \ldots \ldots \ldots \ldots \ldots \ldots \ldots$

Figure 2. Rate of Heat Release Curves for Polyurethane Foam Composites at $25 \mathrm{~kW} / \mathrm{m}^{2}$ Irradiance ................................. 27

Figure 3. Rate of Heat Release Curves for Polyurethane Foam Composites at $35 \mathrm{~kW} / \mathrm{m}^{2}$

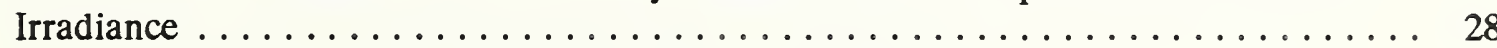

Figure 4. Rate of Heat Release Curves for Polyurethane Foam Composites at $50 \mathrm{~kW} / \mathrm{m}^{2}$ Irradiance . . . . . . . . . . . . . . . . . . . . . . . . . . . . 29

Figure 5. Rate of Heat Release Curves for Melamine Foam Composites at $25 \mathrm{~kW} / \mathrm{m}^{2}$ Irradiance ............................... 30

Figure 6. Rate of Heat Release Curves for Melamine Foam Composites at $35 \mathrm{~kW} / \mathrm{m}^{2}$ Irradiance .................................. 31

Figure 7. Rate of Heat Release Curves for Melamine Foam Composites at $50 \mathrm{~kW} / \mathrm{m}^{2}$ Irradiance ................................. 32

Figure 8. Peak Heat Release versus Time of Peak for 3 Flux Levels $\left(25,35,50 \mathrm{~kW} / \mathrm{m}^{2}\right) . \ldots 33$ 



\title{
Cone Calorimeter Rate of Heat Release Measurements for Upholstered Composites of Polyurethane Foams ${ }^{1}$
}

\author{
Kay M. Villa and Vytenis Babrauskas \\ National Institute of Standards and Technology \\ Building and Fire Research Laboratory \\ Gaithersburg, MD 20899
}

\begin{abstract}
Certain regulatory authorities have recently banned or restricted the use of furniture upholstered with a combination of poly(vinyl chloride) (PVC) covering and a melamine-treated polyurethane foam padding. These actions were taken because of poor performance - as determined by visual observations - in full-scale chair burns. Such behavior was considered unusual since PVC coverings and melamine-treated polyurethane foams, when paired with other fabrics or paddings, generally have been considered to be adequately fire safe.

Correlations have been developed in recent years which allow the use of bench-scale rate of heat release data to predict the full-scale fire hazard. Bench-scale rate of heat release tests were conducted in the Cone Calorimeter. The performance was compared directly against composites using several different types of fabrics and foams. No unusual behavior was found for this composite when examining that rate of heat release variable which has demonstrated predictability to full-scale performance. By examining the test data in detail, it was possible to find several measures, all occurring very early in the specimen combustion, by which this composite showed poorer fire behavior than other specimens. None of those variables, however, are considered to be predictors of full-scale performance. Results are also reported for several other combustion variables, including gas and smoke production.

The results also suggest that potential screening methods (to avoid high testing costs) whereby paddings are tested under standard fabrics and fabrics are tested over standard paddings might have merit.

Only bench-scale tests were conducted in the present study. To resolve this discrepancy between the bench-scale, but quantitative, results obtained here, and full-scale, but qualitative observations reported by others, it would be appropriate to conduct a comparative study in a furniture Calorimeter.
\end{abstract}

Key words: composite materials; Cone Calorimeters; heat release rate; melamine-treated polyurethane foam; nylon; polyolefin; polyurethane foam; polyvinyl chloride; upholstered furniture.

1 This paper is a contribution from the National Institute of Standards and Technology and is not subject to copyright. 


\section{Introduction}

The Cone Calorimeter is a bench-scale test method which has been used to evaluate the flammability performance of furniture materials under conditions of uniform, adjustable irradiance level [1]. The purpose of the study was to utilize the Cone Calorimeter to quantify the combustion characteristics associated with the combination of flexible PVC (polyvinyl chloride) and melaminetreated polyurethane foam. The experiments were designed to directly compare the PVC/melaminetreated polyurethane foam with other typical upholstered fabric and padding combinations.

The City of Boston, Fire Marshal's Office, has noted special flammability problems associated with the specific combination of flexible PVC covering material and melamine-treated polyurethane foam during large-scale furniture burns with the Boston Chair Test [2]. The Boston Chair test exposes a chair, in draft free environment, to a burning paper bag that contains four double sheets of crumbled newspaper. The test uses a subjective visual observation to evaluate the extent of fire growth and smoke production. Chairs made of the PVC/melamine-treated polyurethane materials generally fail the test because of the duration of the fire, high specimen mass loss, rapid flame spread, and the production of large quantities of smoke. Consequently, the flexible PVC/melamine-treated polyurethane foam combination has been banned for commercial upholstery use in the City of Boston [3].

Melamine-treated polyurethane foam $[4,5,6]$ recently has become commercially popular for furniture applications. In the United States, it is commonly used for applications which require an improved flammability performance to a level better than foams which meet the Bunsen burner testing required by the State of California [7]. These foams are commercially displacing the CMHR ${ }^{2}$ (combustion-modified high resilience) polyurethane foams, which had been available earlier, but are heavier and costlier. For brevity, this foam will be referred to hereafter simply as "melamine" foam; this is not to be confused with melamine-formaldehyde foams [8], which are not based on polyurethane, but which are often also referred to as "melamine" foams. The latter are not being used for flexible furniture padding and are not evaluated in the present paper.

Since there is a huge variety of fabrics used in the furniture trade, test methods which require each and every fabric/padding combination to be tested in its as-used assemblage can be costly if implemented for general use. Thus, the furniture industry has long sought schemes whereby a simpler evaluation could be made. Early work in this area suggested that the rate of heat release performance of a fabric/padding composite is, roughly, equivalent to the product of the contribution from the fabric and the contribution from the foam [9]. If such a general behavior were proven, then it would be possible to define screening tests where paddings are tested under standard fabrics and fabrics are tested over standard paddings. If, on the other hand, at least one important counterexample is found where a specific fabric and a padding interact in some 'non-linear' way, then such schemes would not be useful. Since the PVC fabric/melamine foam combination has been held out as showing exactly this behavior, its detailed investigation is of interest.

Note that in some countries the term CMHR is applied also to melamine-treated polyurethane foams; in the United States, however, a distinction is observed - CMHR technology implies a different formulation, and is associated with denser, more heavily filled and fire-retarded products than the melamine-treated foams under discussion. 


\section{Methods}

\subsection{Sampling Plan}

A total of nine fabric and foam combinations were tested at three irradiance levels. Two samples were tested for each flux level and fabric and foam combination. Samples that showed experimental irregularities required an additional sample test. Six tests were also run to determine baseline values for the foams alone; a total of 60 tests were performed in the entire series. The order for sample testing was randomized within each irradiance flux level.

\subsection{Materials $^{3}$}

The combinations selected for testing were chosen to include several common types of materials against which a direct comparison could be made. For each material variable (fabric, padding, interbarrier), at least one substantively different type was chosen. The test samples procured for testing consisted only of commonly available, commercially produced materials. The nine combinations tested were:

- nylon covering over polyurethane foam

- nylon covering over melamine-treated polyurethane foam

- nylon covering over melamine-treated polyurethane foam with interbarrier

- polyolefin covering over polyurethane foam

- polyolefin covering over melamine-treated polyurethane foam

- polyolefin covering over melamine-treated polyurethane foam with interbarrier

- poly(vinyl chloride) covering over polyurethane foam

- poly(vinyl chloride) covering over melamine-treated polyurethane foam

- poly(vinyl chloride) covering over melamine-treated polyurethane foam with interbarrier. For future reference these materials will be referred to as nylon/PU, nylon/melamine, nylon/melamine/interbarrier, polyolefin/PU, polyolefin/melamine, polyolefin/melamine/interbarrier, $\mathrm{PVC} / \mathrm{PU}$, $\mathrm{PVC} /$ melamine, and PVC/melamine/interbarrier ${ }^{4}$.

The nylon fabric covering was a residential weight fabric $\left(352 \mathrm{~g} / \mathrm{m}^{2}\right)$, green color, $100 \%$ nylon, plain weave, $1.4 \mathrm{~m}$ wide, warp of 10 yarns $/ 2.54 \mathrm{~cm}$ of 30 ply $/ 37$ tex fibers, weft of 9 yarns $/ 2.54 \mathrm{~cm}$ of 30 ply $/ 37$ tex fibers, fabric thickness of $1.5 \mathrm{~mm}$, and acrylic backed with a Scotchguard ${ }^{\mathrm{TM}}$ surface finish. The polyolefin fabric covering was $186 \mathrm{~g} / \mathrm{m}^{2}$, black color, $100 \%$ polyolefin, plain weave, 1.4 $\mathrm{m}$ wide, warp of 20 yarns $/ 2.54 \mathrm{~cm}$ of 30 ply $/ 272$ tex fibers, weft of 20 yarns $/ 2.54 \mathrm{~cm} 30$ ply/272 tex fibers, fabric thickness of $0.5 \mathrm{~mm}$, with an acrylic backing. The flexible poly(vinyl chloride) covering comprised four layers: the top layer $(0.25 \mathrm{~mm})$ was plasticized PVC, as was the second layer $(0.74$ $\mathrm{mm})$. The third layer was an adhesive $(0.035 \mathrm{~mm})$, while the bottom layer was a knit poly(ethylene

3 Identification of materials does not imply recommendation or endorsement by the National Institute of Standards and Technology.

4 The reader should note that only one type of each kind of material (foam, fabric) was used in this project. We do not imply that all PVC coverings, for example, would behave like this one cited in this study. Nor can any of the above combinations be extrapolated to infer the flammability behavior of all materials that belong to these specific classifications. 
terephthalate) fabric $(0.13 \mathrm{~mm})$. This was a commercial sample and the manufacturer said that it did not include any fire retardants, and represented an older type "formulation" of PVC. The sample had an areal density of $823 \mathrm{~g} / \mathrm{m}^{2}$, and was burgundy in color, supplied as $1.5 \mathrm{~m}$ wide.

The conventional polyurethane foam had a density of $32 \mathrm{~kg} / \mathrm{m}^{3}$, white color, indentation force deflection ${ }^{5}$ of 45 , and a fine pore structure. The melamine-treated polyurethane foam had a density of $48 \mathrm{~kg} / \mathrm{m}^{3}$, peach color, indentation force deflection rating of 35 , and a medium-sized pore structure. The interbarrier padding was a garnetted nonwoven web of polyester fiber attached by polyester thread to a lightweight spunbonded polyester nonwoven, areal density of $415 \mathrm{~g} / \mathrm{m}^{2}$, white color, with a $10 \mathrm{~cm}$ loft depth.

\subsection{Sample Preparation}

The samples were cut to the following sizes: fabric coverings were cut as a cruciform $200 \mathrm{~mm}$ by $200 \mathrm{~mm}$, with $50 \mathrm{~mm}$ by $50 \mathrm{~mm}$ squares cut out from each corner. Foams were $100 \mathrm{~mm}$ by 100 $\mathrm{mm}$ by $50 \mathrm{~mm}$; the interbarrier samples were $100 \mathrm{~mm}$ by $100 \mathrm{~mm}$. After cutting, the materials were conditioned in an environment of $55 \%$ relative humidity at $21^{\circ} \mathrm{C}$ for $24 \mathrm{~h}$, at which time the samples were weighed to determine the average material densities. The materials were then assembled as upholstery composite sample structures. The side flaps of the covering were brought down along the sides of the foam block. Each outside edge was attached to the bottom of the foam with a staple. The four sets of side edges were attached to one another with two additional staples. A total of twelve staples were used in each composite sample; four on the bottom, eight along the side edges. The bottom of the composite structure had no fabric covering. Samples containing the interbarrier had this material layered between the covering and the foam block. The interbarrier was located only in the top plane of the composite structure. The composite structure was weighed and the data recorded. Finally, the composite structure was wrapped in a single piece (200 $\mathrm{mm}$ by $200 \mathrm{~mm})$ of heavy duty aluminum foil. The foil was shaped to cover the bottom and the sides of the composite structure, leaving the top of the sample exposed. The composite structures remained in the conditioned environment until two minutes before testing in the Cone Calorimeter.

\subsection{Cone Calorimeter}

The Cone Calorimeter is described in detail in [10]. It is based upon the oxygen consumption principle, which states that the combustion heat released by a burning specimen is proportional to the total amount of oxygen consumed in the combustion process. The Cone Calorimeter exposes a sample to an external heating flux, while also simultaneously recording its mass on a load cell. Ignition is by the use of an electric spark, which does not add localized heating. The heat release rate is determined by making appropriate measurements on the exhaust gas stream.

The Calorimeter (Fig. 1) uses a radiant, conical-shaped coil heater which can deliver heating fluxes to the specimen that may be set from 0 to $100 \mathrm{~kW} / \mathrm{m}^{2}$. Samples can be exposed in both horizontal and vertical orientations, but all of the samples in this study were tested under horizontal orientation conditions. The time at which the sample begins to show sustained visible flaming is defined as the ignition time of the sample. The sample is allowed to burn until all flames go out; two minutes later, the experiment is terminated. During the test, the following measurements are taken at $5 \mathrm{~s}$ intervals: (a) oxygen concentration in the exhaust duct, along with the exhaust flow, as

5 Indentation force deflection is known as IFD. The foam is compressed to $25 \%$ of its normal height, measured in units of $\mathrm{lbs} / 50 \mathrm{in}^{2}$. 
measured by pressure and temperature readings from a sharp-edged orifice plate flowmeter; (b) the mass remaining of the specimen; (c) visible smoke obscuration, as determined by a laser-beam photometer; (d) the production of various combustion gases $\left(\mathrm{CO}, \mathrm{CO}_{2}\right.$, total unburned hydrocarbons, and water vapor). Finally, the production of soot is not monitored on a time-resolved basis, but is determined as a single, test-average value. The test is conducted according to procedures specified in ASTM E 1354 [11]. References for equations and calculations to determine Cone Calorimeter measured parameters are discussed by Babrauskas [10] and Parker [12]. The detailed operating procedures for the instrument that are followed during testing are set out in a user's guide [13].

Since the Cone Calorimeter is a general-purpose instrument, used for testing various classes of products, a standard heating flux to be used is not specified. For residential-use upholstered furniture, a level of $25 \mathrm{~kW} / \mathrm{m}^{2}$ has been used [2]. For institutional-use furniture, or for items intended for high risk occupancies, higher levels of heating flux are generally necessary to characterize specimen performance adequately. Thus, in the present study, tests were conducted at 25,35 , and $50 \mathrm{~kW} / \mathrm{m}^{2}$.

Earlier studies on upholstered furniture have shown that the rate of heat release values obtained from the Cone Calorimeter can be used to predict the full-scale rate of heat release curve [1]. The Cone Calorimeter was adopted for the present study precisely since these earlier studies have validated the use of its data for full-scale fire modeling predictions. In addition to the rate of heat release, smoke measurements on upholstered furniture specimens from the Cone Calorimeter have also been validated against the full scale [14].

\section{Results and Discussion}

\subsection{Ignitability}

The materials tested were evaluated for: ignition delay time; percent mass loss; total heat release; the effective heat of combustion; peak heat release rate; heat release rates averaged for time periods of 15,120 , and $180 \mathrm{~s}$ after ignition; and the production of carbon monoxide, carbon dioxide, water vapor, total unburned hydrocarbons, and smoke.

Visual observation of the specimens showed that after being exposed to the heating flux, the PVC covering formed a liquid on the surface of the sample. The composite then expanded into a mound; white-colored bubbling occurred on the surface; after several seconds it turned gray, and then the sample ignited. The polyolefin fabric melted immediately - its edges curled back and exposed the foam beneath. The ease with which this occurred may have been due to the low areal density of the fabric. The nylon fabric exhibited the greatest resistance to the heat before melting. Several seconds of exposure time were required before the nylon covering melted. Later the sample began to flame. Exposure of the melamine foam caused it to bubble and melt away from the heat source. The polyurethane foam initially swelled upon heating and then melted and receded from the heat. The polyurethane foam ignited very fast. Specimens using the interbarrier generally produced very black and sooty combustion products.

Post-test observations include the following comments. The plain polyurethane composites generally underwent complete volatilization, while the melamine-treated foams did not, with approximately $20 \%$ of the foam volume remaining in the sample pan. The remains of this material were dark gray, smooth, and dry. The top surface was convex and the material had a molten 
appearance. The nylon fabric covering produced a black residue in the aluminum pan, while the PVC covering produced a rust-brown residue.

Times to ignition are given in Table 1 . The shortest value for time to ignition was the polyolefin/PU composites, followed by the PVC/PU, PVC/melamine and PVC/melamine/interbarrier combinations. The nylon/melamine combinations exhibit the greatest resistance to ignition. (The value for the $25 \mathrm{~kW} / \mathrm{m}^{2}$ sample of nylon/melamine combination represents only one sample because the two other samples tested did not ignite after being exposed to the heat flux for 10 minutes.) In general, time to ignition decreased for increasing fluxes for all the materials. The relative rankings did not depend on the flux level but did depend on both the foam and the covering, as follows:

$\begin{array}{cll} & \text { PU foam } & \text { Melamine-treated foam } \\ \text { shortest time } & \text { bare } & \text { PVC } \\ \downarrow & \text { polyolefin } & \text { polyolefin } \\ \downarrow & \text { PVC } & \text { nylon } \\ \text { longest time } & \text { nylon } & \text { bare }\end{array}$

The rank order for the melamine-treated polyurethane composites at $50 \mathrm{~kW} / \mathrm{m}^{2}$ is not as clearly defined, the time to ignition is comparable for all of the fabrics. It can be noted that the one ignition time for the bare melamine foam, at $25 \mathrm{~kW} / \mathrm{m}^{2}$ and $35 \mathrm{~kW} / \mathrm{m}^{2}$, would indicate extremely good ignition performance; this was not borne out by the melamine foam results where a foam and fabric composite was tested at 25 or $35 \mathrm{~kW} / \mathrm{m}^{2}$ irradiance. In these cases, for the melamine foam composites, the time to ignition performance was identical to PU foams in one case (PVC covering) and better than PU in two others (nylon, polyolefin). At the highest $\left(50 \mathrm{~kW} / \mathrm{m}^{2}\right)$ irradiance, the anomalous behavior of bare melamine foam was no longer evident - the ignition times for bare melamine foam and for foam + fabric composites were roughly similar. The use of the interbarrier slightly increased the time to ignition for most of the composites, exceptions include a decreased time to ignition for nylon/interbarrier/melamine and significant increases for nylon/interbarrier/melamine and polyolefin/interbarrier/melamine at $50 \mathrm{~kW} / \mathrm{m}^{2}$.

The times to ignition for the PVC/melamine composites were among the fastest, but not as fast as the polyolefin/PU specimens. Since systematic study of upholstered furniture flammability has shown the time to ignition not to be correlated to the fire hazard developed from burning items of upholstered furniture [1], this finding is not judged to reflect any unusual hazard potential of the $\mathrm{PVC} /$ melamine combination.

\subsection{Mass Loss and Total Heat Released}

The percent mass loss for the specimens are given in Table 2. There appears to be only small differences between the different composites, the data suggest that the samples burned to approximately less than or equal to one quarter of their original mass, except for nylon/melamine and nylon/interbarrier/melamine at the $25 \mathrm{~kW} / \mathrm{m}^{2}$ exposure.

In some cases, improved fire-retardant materials can show substantial improvements in the total heat released or in the measured heat of combustion [15]. Thus, these diagnostic measurements are tabulated in Table 3 (total heat released) and Table 4 (effective heat of combustion). The results do not indicate any significant performance differences between the melamine/PVC samples and the other composites studied. 


\subsection{Rate of Heat Release}

An extensive series of studies conducted at NIST in previous years [1] had identified that the single most important hazard component associated with upholstered furniture fires is the peak rate of heat release. Correlation studies, in turn, showed that this full-scale variable can be predicted by an equation which relies primarily on the bench-scale rate of heat release. The rate of heat release variable used in these correlations was the average for the $180 \mathrm{~s}$ post-ignition. The correlation is predicated also on the specifying of the specimen irradiance at the $25 \mathrm{~kW} / \mathrm{m}^{2}$ level [16]. Table 5 gives the test results. It is clear by this measure that the PVC/melamine combination is the best, not the worst, of the test materials. The data at the two higher irradiances also produce similar rankings.

The peak rate of heat release rate values (averaged over replicate samples) are listed in Table 6. Again, no anomalies of the PVC/melamine specimens were seen. For all of the composite specimens, peak heat release rate sensibly increased as irradiance increases. The bare PU foam showed quite high, but not the highest values, while the bare melamine foam showed the lowest values of all. When a fabric cover was added to the PU foam, the rate increased in the case of nylon and polyolefin, but decreased in the case of PVC. With melamine, however, such trends were not repeated. Instead, adding any of the three cover fabrics, including PVC, increased the rate of heat release. Generally, the polyurethane foam composites had peak heat releases equal to or greater than $450 \mathrm{~kW} / \mathrm{m}^{2}$ while the melamine foam composites were less than $450 \mathrm{~kW} / \mathrm{m}^{2}$. The effects of adding an interliner were not large nor consistent over the different flux levels.

Examination of the complete curves of the rate of heat release (Figures 2 - 7) suggested that burning anomalies of the PVC/melamine composites might be seen in the early period of combustion; thus, rate of heat release values for $15 \mathrm{~s}$ and for $120 \mathrm{~s}$ post-ignition are presented in Tables 7 and 8. For the $120 \mathrm{~s}$ averages, the PVC/melamine combinations show the least rate of heat release at all flux levels. Only for the very short $15 \mathrm{~s}$ averaging period (Table 8), are somewhat different results seen. Over this $15 \mathrm{~s}$ period, the PVC/melamine results are, indeed, higher at any given flux level than the comparable ones from nylon/melamine or polyolefin/melamine. Similarly, if PVC covering is specified and foam material is varied, then, at the 25 and $35 \mathrm{~kW} / \mathrm{m}^{2}$ irradiances, the melamine composite performs worse than both the PU and the melamine/interbarrier composites. The above comparative differences, however, are not very large quantitatively. Overall, at the $15 \mathrm{~s}$ averaging period, only nylon/melamine, nylon/melamine/interbarrier, and the polyolefin/melamine/interbarrier combinations emerge as significantly better than the rest, at least at the lower irradiances. The Cone Calorimeter rate of heat release data for $\mathrm{PVC} /$ melamine composites exhibit only minor differences, during the early stages of testing, when compared to the other fabric and foam combinations.

Further details are evident in the heat release rate plots. Figs. 2 through 4 represent the curves for the PU composites, while Figs. 5 through 7 are for the melamine and melamine/interbarrier composites. Each figure contains one flux level. For all three polyurethane composite graphs one can see an increase in the peaks of the rate of heat release and decreases in the time for testing with increasing flux level. The curves for the polyurethane foam, nylon/PU, and polyolefin/PU are similar in shape. In Fig. 3 the nylon/PU and polyolefin/PU curves are slightly greater in magnitude and timeshifted to the right of the polyurethane curve. The addition of a nylon or polyolefin fabric covering to the polyurethane foam appears to be additive or linear. The PVC/PU curve appears to be very different. The curve has a steep initial slope which drops off quickly. Then the curve decreases gradually, but after a period of 150 seconds there is another peak. The second peak reaches the same height as the first, but is spread wider, over approximately 250 seconds. At $35 \mathrm{~kW} / \mathrm{m}^{2}$ (Fig. 4) the polyolefin/PU, nylon/PU, and polyurethane curves again are very similar in shape and size. The composites with the fabric coverings are higher in value and more protracted in time, compared to the bare polyurethane curve. Again, the PVC/PU curve is different from the others. The PVC/PU 
curve is similar to the PVC/PU curve at the lower irradiance, but it reaches a higher initial peak, has shorter trough, and a second peak which is much higher and steeper. At $50 \mathrm{~kW} / \mathrm{m}^{2}$ irradiance (Fig. 5), the polyurethane, nylon/PU, and polyolefin/PU curves have the same general shape as at the lower irradiances. The PVC/PU curve, which showed a shallow plateau at the $25 \mathrm{~kW} / \mathrm{m}^{2}$ tests, shows a deep plateau in the 35 and $50 \mathrm{~kW} / \mathrm{m}^{2}$ ones. For all fabric/foam combinations, at $50 \mathrm{~kW} / \mathrm{m}^{2}$ the peak height ratio for the second peak, compared to the first peak is much larger than at lower heating fluxes. Since the second peak can, roughly, be considered to be dominated by the foam behavior, while the first peak is dominated by fabric performance, it can be concluded that foam response is nearly proportional to heating flux, while the fabric response is fairly insensitive to heating flux.

This same sharp initial peak (attributable largely to the fabric) is also evidenced in the melamine composite rate of heat release curves (Figs. 6, 7, and 8). These curves are strikingly different from the PU ones, however, in that the burning time - and in many cases, the ignition time - were much longer. The peak heights for the second peak were, in most cases, similar to the height of the first peak. By contrast, for the PU composites, at the highest irradiance level the second peak was about double the height of the initial peak. The nylon/melamine and nylon/melamine/interbarrier composites are clearly identifiable by their very long times to ignition. When ignited, however, these specimens burned to completion in a slightly shorter length of time than the ignition-to-burnout times recorded for the comparable PU specimens. The PVC/melamine and PVC/melamine/interbarrier composites exhibited a steep and high initial peak, occurring within the first 15 to $20 \mathrm{~s}$ after ignition. The PVC/melamine peak was higher than the PVC/melamine/interbarrier peak.

At the $25 \mathrm{~kW} / \mathrm{m}^{2}$ irradiance (Fig. 6), the bare melamine foam did not ignite and can be seen as only a small trace along the $\mathrm{X}$-axis at approximately 50 seconds. The PVC/melamine composites had a high initial peak which then dips briefly, then maintains a slow, long plateau. The $\mathrm{PVC} /$ melamine composites burned approximately twice as long as the other composites tested, 800 s. The peak rate of heat release values for all of the composites were very similar, however the PVC composites reach their peak the earliest.

At $35 \mathrm{~kW} / \mathrm{m}^{2}$ irradiance (Fig. 7), all of the samples ignited much faster, and exhibited shorter combustion times. The bare melamine foam took a very long time to ignite and showed only a single peak. The polyolefin/melamine and polyolefin/melamine/interbarrier curves are similar in shape to the ones at the lower irradiance, but are shifted to the left. The nylon/melamine and nylon/melamine/interbarrier composites are dramatically shifted to the left, and the shape of the nylon/melamine curve looks more like a plateau than the curve in Fig. 6 . The PVC/melamine and $\mathrm{PVC} / \mathrm{melamine} /$ interbarrier curves have very similar shaped curves as at the $25 \mathrm{~kW} / \mathrm{m}^{2}$ irradiance; however the peak values are higher by about $50 \mathrm{~kW} / \mathrm{m} 2$ and the burning time is decreased by $25 \%$. The PVC/melamine peak rate of heat release is equivalent to that for nylon/melamine $\left(350 \mathrm{~kW} / \mathrm{m}^{2}\right)$, but occurs much quicker.

For the $50 \mathrm{~kW} / \mathrm{m}^{2}$ flux level (Fig. 8), all the curves show much faster times to ignition, and much shorter burning times. The PVC/melamine and PVC/melamine/interbarrier composites exhibit very similar curves to the 25 and $35 \mathrm{~kW} / \mathrm{m}^{2}$ curves, but exhibit faster burning and a higher rate of heat release. In contrast to the other specimens, the PVC/melamine composites reached their peak heat release rate within fifteen to twenty seconds and decreased thereafter. The bare melamine foam sample shows two peaks, with the second being slightly higher than the first. For comparison, this curve is rather similar to the polyolefin/melamine curve at the $25 \mathrm{~kW} / \mathrm{m}^{2}$ flux level. Unlike at lower fluxes, the nylon/melamine/interbarrier composites clearly had the highest peak rate of heat release at the $50 \mathrm{~kW} / \mathrm{m}^{2}$ level.

Finally, since the times to ignition were among the fastest for the $\mathrm{PVC} /$ melamine specimens, it was of interest to examine a related quantity, the time at which the peak rate of heat release occurred. Figure 8 shows a cross-plot of peak heat release rate values, plotted against the time at 
which the peak occurred. The PVC/melamine and PVC/melamine/interbarrier composites reached their peak heat release in fifteen to twenty seconds, which was the fastest of all of the composites tested. The nylon/melamine and nylon/melamine/interbarrier composites at the 25 and $35 \mathrm{~kW} / \mathrm{m}^{2}$ flux levels gave the longest time to reach their peak heat release rate. [Again, as for the times to ignition, no particular hazard interpretation is attached to this finding.]

\subsection{Yields of Other Products of Combustion}

In the Cone Calorimeter, measurements of $\mathrm{CO}, \mathrm{CO}_{2}, \mathrm{H}_{2} \mathrm{O}$, and total hydrocarbons are routinely made. These measurements are useful in characterizing the combustion; they can also have application to product evaluations, although recent scaling studies suggest that the relationships may not be simple [15].

Carbon monoxide production data is shown in Table 9. The role of irradiance level on the production of carbon monoxide appears to be minimal for all of the materials tested. The Cone Calorimeter testing procedure utilizes over ventilated burning conditions which can provide a means for low $\mathrm{CO}$ production. The $\mathrm{PVC} /$ foam specimens, however, showed a substantially greater production of $\mathrm{CO}$ than the other fabric/foam combinations.

The results for $\mathrm{CO}_{2}, \mathrm{H}_{2} \mathrm{O}$, and total unburned hydrocarbons are shown in Tables 10 through 12 , respectively. The only significant performance differences noted are of the fabric type on the yield of total unburned hydrocarbons, where the PVC-fabric results are distinctly higher than those for the other fabric/foam combinations tested.

Results for the production of smoke are given in Table 13. The largest smoke production values were for the PVC assemblies, the smoke production from the nylon and the polyolefin assemblies were generally similar, and was typically one half those from the comparable PVC assemblies. The presence of the interbarrier in each of the composites increased the amount of smoke produced, but the data clearly indicate that smoke production was, in all cases, dominated by the fabric material. The values for the bare foams were substantially lower than the fabric and foam assemblies. Since smoke yields in Cone Calorimeter measurements have been correlated to full-scale performance [14], the above findings can be interpreted to relate directly to the full-scale hazard, where the greater the amount of smoke there is an exhibited increase in flame radiation which produces faster fire growth.

\section{Conclusions}

- There were no significant bench-scale differences in the flammability behavior of the PVC/melamine-treated polyurethane composites from the other material composites tested. Physical properties that showed no significant differences include: average rate of heat release; total heat release; and effective heat of combustion.

- After a detailed study of the experimental data, the only area that indicated poor fire behavior for the PVC/melamine foam composites were in the early stages of fire development. Three variables were found by which the PVC/melamine specimens showed unusual behavior: (1) the time to ignition; (2) the time to reach the peak rate of heat release; and (3) the rate of heat release averaged over the first $15 \mathrm{~s}$ post-ignition. In order to make a direct correlation of these three variables, with respect to full-scale testing, another set of experiments should be executed using identical PVC/melamine- 
treated polyurethane foam materials, constructed as appropriately scaled specimens, in the Cone Calorimeter and the Furniture Calorimeter.

- The PVC/melamine composites were also different from the other specimens tested, in that they tended to burn over a longer period of time. Length of bench-scale specimen burn time is, again, not correlated to any specific hazard in the full-scale. This could only be predicted by full-scale experimentation of the same materials in actual end-use application.

- The highest values of $\mathrm{CO}$, total unburned hydrocarbons, and smoke were all associated with those specimens using PVC fabrics, irrespective of foam type or of the presence of an interbarrier. Previous fire research on smoke development has shown that bench-scale smoke behavior can be correlated to the full-scale smoke hazard, where the more opaque the upper smoke layer, generally the faster flashover occurs in the room. For $\mathrm{CO}$, however, similar predictive relationships are not yet available.

- We emphasize that only a non-fire-retarded PVC covering of a somewhat older type was evaluated in this program. PVC flammability issues are being addressed by a number of manufacturers who, more recently, have been developing improved, fire-retardant grades of PVC.

- This study was limited in that one specific material represented a given generic class, i.e., nylon, melamine-treated polyurethane foam, therefore, one can not assume that the flammability behavior of the individual specimen translates to the entire generic class.

- It should be noted that all of the tests conducted in the present study were limited to bench-scale tests. As with any flammability phenomenon where the possibility of anomalous behavior is being examined, the final verification has to be done by conducting tests which are both (a) large-scale and (b) quantitative.

- The intent of this study was to examine for general anomalous trends of small-scale flammability behavior for several combinations of fabrics and foam, the study was statistically limited with the use of two replicates per given composite at one irradiance exposure.

- This study incorporated a number of specimens where foams and fabrics were separately varied in a controlled manner, the composites showed tendencies towards synergistic or antagonistic behavior which may appear to be linear or additive. The present study was not large enough to offer definitive conclusions on the additive nature of upholstered furniture composites, however, further work in this area may provide a model for simplified analysis of upholstered furniture composites.

- The flammability test results for bare foam do not indicate the flammability properties of a fabric and foam composite. The present study confirmed what has generally been known about melamine foams: when tested bare they tend to be extremely difficult to ignite; whereas when these foams are tested with an upholstery fabric covering the ignition times are much faster.

- Of general interest in the interpretation of rate of heat release data, the present study offers some interpretation of the relative response of the foam versus the fabric material. The data obtained here show that foam response is nearly proportional to the applied irradiance, while the fabric response is fairly insensitive to the range of irradiances tested. 


\section{References}

[1]. Babrauskas, V., and Krasny, J.F., Fire Behavior of Upholstered Furniture (NBS Monograph 173). [U.S.] Nat. Bur. Stand. (1985).

[2]. City of Boston, Fire Department, Fire Department Chair Test, Boston, MA pg.1-5, 1986.

[3]. City of Boston, Fire Department, Approved Upholstery Foam Product List, Boston, MA pg.14, February 1987.

[4]. Grace, O.M., Mericle, R.E., and Taylor, J.D., Melamine Modified Polyurethane Foam, J. of Cellular Plastics, vol. 8, no. 5, 311-317 (Sept/Oct 1985).

[5]. Smiecinski, T.M., Grace, O.M., and Wujcik, S.E., Melamine Polyurethane Flexible Foams, pp. 104-114 in Proc. 13th Intl. Conf. on Fire Safety, Product Safety Corp., Millbrae, CA (1988).

[6]. Grace, O.M., Performance of Foam and Fabric Composites in Large Scale Furniture Flammability Tests, Proc. 14th Intl. Conf. on Fire Safety, Product Safety Corp., Millbrae, CA (1989).

[7]. Flammability Information Package (Contains Technical Bulletins 116, 117, 121, and 133). Bureau of Home Furnishings, Dept. of Consumer Affairs, State of California, North Highlands (1985).

[8]. Krückau, F., Melamine Foam for Sound and Heat Insulation, Plastics in Bldg. Constr., 10 (1), 5-6 (1986).

[9]. Babrauskas, V., Upholstered Furniture Heat Release Rates: Measurements and Estimation, J. of Fire Sciences, 1, 9-32 (1983).

[10]. Babrauskas, V., Development of the Cone Calorimeter - A Bench Scale Heat Release Rate Apparatus Based on Oxygen Consumption, Fire and Materials, 8, 81-95 (1984).

[11]. Proposed Test Method for Heat and Visible Smoke Release Rates for Materials and Products using an Oxygen Consumption Calorimeter E 1354-90a, Annual Book of ASTM Standards, Vol. 04.07, American Society for Testing and Materials, Philadelphia (1991).

[12]. Parker, W.J., Calculations of the Heat Release Rate by Oxygen Consumption for Various Applications, J. Fire Sciences, 2, 380-395 (1984).

[13]. Twilley, W.H., and Babrauskas, V., User's Guide for the Cone Calorimeter, Edition 1, [U.S.] Natl. Bur. Stand. (1988).

[14]. Babrauskas, V., and Mulholland, G., Smoke and Soot Data Determinations in the Cone Calorimeter, pp. 83-104 in Mathematical Modeling of Fires (ASTM STP 983). American Society for Testing and Materials, Philadelphia (1987). 
[15]. Babrauskas, V., Harris, R.H., Jr., Gann, R.G., Levin, B.C., Lee, B.T., Peacock, R.D., Paabo, M., Twilley, W., Yoklavich, M.F., and Clark, H.M., Fire Hazard Comparison of Fire-Retarded and Non-Fire-Retarded Products (NBS Special Publication SP 749). [U.S.] Natl. Bur. Stand. (1988).

[16]. Babrauskas, V., and Krasny, J.F., Prediction of Upholstered Chair Heat Release Rates from Bench-Scale Measurements, pp. 268-284 in Fire Safety Science and Engineering (ASTM STP 882), T.Z. Harmathy, ed., Amer. Soc. for Testing and Materials (1985). 
Table 1. Time to Ignition ${ }^{6}$

(seconds)

\begin{tabular}{|c|c|c|c|c|c|c|c|c||}
\hline \multicolumn{3}{|c|}{ Composite Materials } & \multicolumn{7}{c|}{$\begin{array}{c}\text { Flux Level } \\
\left(\mathrm{kW} / \mathrm{m}^{2}\right)\end{array}$} \\
\hline Fabric & Foam & Interbarrier & 25 & $\begin{array}{c}\text { CV } \\
\%\end{array}$ & 35 & $\begin{array}{c}\text { CV } \\
\%\end{array}$ & 50 & $\begin{array}{c}\text { CV } \\
\%\end{array}$ \\
\hline Nylon & Polyurethane & No & 16 & 0 & 9 & 24 & 0 & 33 \\
\hline Nylon & Melamine & No & $523^{*}$ & - & 120 & 56 & 6 & 9 \\
\hline Nylon & Melamine & Yes & 429 & 16 & 142 & 9 & 23 & 1 \\
\hline Polyolefin & Polyurethane & No & 7 & 24 & 4 & 9 & 3 & 21 \\
\hline Polyolefin & Melamine & No & 32 & 47 & 9 & 38 & 9 & 25 \\
\hline Polyolefin & Melamine & Yes & 63 & 12 & 25 & 2 & 12 & 42 \\
\hline PVC & Polyurethane & No & 13 & 17 & 0 & 6 & 5 & 27 \\
\hline PVC & Melamine & No & 13 & 11 & 7 & 5 & 5 & 2 \\
\hline PVC & Melamine & Yes & 13 & 33 & 5 & 2 & 6 & 21 \\
\hline- & Polyurethane & No & $4^{*}$ & - & $3^{*}$ & - & $1^{*}$ & - \\
\hline- & Melamine & No & NI* & - & $227^{*}$ & - & $6^{*}$ & - \\
\hline
\end{tabular}

* - Single Determination

NI - No Ignition

6 The values given are for the average of, typically, 2 tests. The coefficients of variation (CV) are given for those cases where sufficient experimental data were available, a dash (-) means that a coefficient of variation could not be determined. 
Table 2. Percent Mass Loss

(\%)

\begin{tabular}{||c|c|c|c|c|c|c|c|c||}
\hline \multicolumn{3}{|c|}{ Composite Materials } & \multicolumn{7}{c||}{$\begin{array}{c}\text { Flux Level } \\
\left(\mathrm{kW} / \mathrm{m}^{2}\right)\end{array}$} \\
\hline Fabric & Foam & Interbarrier & 25 & $\begin{array}{c}\text { CV } \\
\%\end{array}$ & 35 & $\begin{array}{c}\text { CV } \\
\%\end{array}$ & 50 & $\begin{array}{c}\text { CV } \\
\%\end{array}$ \\
\hline Nylon & Polyurethane & No & 91 & 1 & 93 & 2 & 93 & 2 \\
\hline Nylon & Melamine & No & $57^{*}$ & - & 74 & 8 & 82 & 1 \\
\hline Nylon & Melamine & Yes & 66 & 2 & 78 & 3 & 82 & 0.2 \\
\hline Polyolefin & Polyurethane & No & 93 & 0.3 & 94 & 1 & 90 & 0.6 \\
\hline Polyolefin & Melamine & No & 79 & 0.1 & 79 & 1 & 79 & 3 \\
\hline Polyolefin & Melamine & Yes & 80 & 1 & 82 & 1 & 80 & 0.1 \\
\hline PVC & Polyurethane & No & 87 & 5 & 80 & 0.2 & 88 & 1 \\
\hline PVC & Melamine & No & 76 & 2 & 79 & 1 & 79 & 1 \\
\hline PVC & Melamine & Yes & 75 & 4 & 78 & 1 & 92 & 13 \\
\hline- & Polyurethane & No & $94^{*}$ & - & $93^{*}$ & - & $96 *$ & - \\
\hline & Melamine & No & NI* & - & $43^{*}$ & - & $78^{*}$ & - \\
\hline
\end{tabular}

* - Single Determination

NI - No Ignition

$(-)$ - Coefficient of variation could not be determined. 
Table 3. Total Heat Release

$$
\left(\mathrm{MJ} / \mathrm{m}^{2}\right)
$$

\begin{tabular}{||c|c|c|c|c|c|c|c|c||}
\hline \multicolumn{3}{|c|}{ Composite Materials } & \multicolumn{5}{c|}{$\begin{array}{c}\text { Flux Level } \\
\left(\mathrm{kW} / \mathrm{m}^{2}\right)\end{array}$} \\
\hline Fabric & Foam & Interbarrier & 25 & $\begin{array}{c}\text { CV } \\
\%\end{array}$ & 35 & $\begin{array}{c}\text { CV } \\
\%\end{array}$ & 50 & $\begin{array}{c}\text { CV } \\
\%\end{array}$ \\
\hline Nylon & Polyurethane & No & 72 & 1 & 74 & 1 & 73 & 1 \\
\hline Nylon & Melamine & No & $49 *$ & 1 & 64 & 7 & 72 & 1 \\
\hline Nylon & Melamine & Yes & 65 & 4 & 72 & 3 & 80 & 1 \\
\hline Polyolefin & Polyurethane & No & 62 & 0 & 63 & 1 & 63 & 0 \\
\hline Polyolefin & Melamine & No & 59 & 4 & 69 & 1 & 69 & 0 \\
\hline Polyolefin & Melamine & Yes & 68 & 4 & 69 & 4 & 69 & 1 \\
\hline PVC & Polyurethane & No & 67 & 1 & 68 & 2 & 68 & 1 \\
\hline PVC & Melamine & No & 68 & 7 & 71 & 4 & 68 & 1 \\
\hline PVC & Melamine & Yes & 75 & 1 & 74 & 6 & 77 & 0 \\
\hline- & Polyurethane & No & $44^{*}$ & - & $45^{*}$ & - & $43^{*}$ & - \\
\hline- & Melamine & No & NI* & - & $25^{*}$ & - & $40^{*}$ & - \\
\hline
\end{tabular}

* - Single Determination

NI - No Ignition

$(-)$ - Coefficient of variation could not be determined. 
Table 4. Effective Heat of Combustion

(MJ/kg of sample)

\begin{tabular}{||c|c|c|c|c|c|c|c|c||}
\hline \multicolumn{3}{|c|}{ Composite Materials } & \multicolumn{7}{c||}{$\begin{array}{c}\text { Flux Level } \\
\left(\mathrm{kW} / \mathrm{m}^{2}\right)\end{array}$} \\
\hline Fabric & Foam & Interbarrier & 25 & $\begin{array}{c}\text { CV } \\
\%\end{array}$ & 35 & $\begin{array}{c}\text { CV } \\
\%\end{array}$ & 50 & $\begin{array}{c}\text { CV } \\
\%\end{array}$ \\
\hline Nylon & Polyurethane & No & 28 & 1 & 27 & 0.3 & 28 & 0.5 \\
\hline Nylon & Melamine & No & $26^{*}$ & - & 24 & 0.3 & 25 & 2 \\
\hline Nylon & Melamine & Yes & 24 & 1 & 23 & 0 & 24 & 1 \\
\hline Polyolefin & Polyurethane & No & 30 & 0.2 & 30 & 0.5 & 32 & 1 \\
\hline Polyolefin & Melamine & No & 26 & 1 & 25 & 1 & 26 & 4 \\
\hline Polyolefin & Melamine & Yes & 24 & 0 & 23 & 2 & 25 & 1 \\
\hline PVC & Polyurethane & No & 18 & 4 & 19 & 1 & 18 & 0.4 \\
\hline PVC & Melamine & No & 18 & 1 & 18 & 1 & 18 & 1 \\
\hline PVC & Melamine & Yes & 18 & 6 & 17 & 2 & 15 & 19 \\
\hline- & Polyurethane & No & $27^{*}$ & - & $28^{*}$ & - & $27^{*}$ & - \\
\hline- & Melamine & No & NI* & - & $23^{*}$ & - & $21^{*}$ & - \\
\hline
\end{tabular}

* - Single Determination

NI - No Ignition

$(-)$ - Coefficient of variation could not be determined. 
Table 5. 180 Second Interval Rate of Heat Release

$\left(\mathrm{kW} / \mathrm{m}^{2}\right)$

\begin{tabular}{||c|c|c|c|c|c|c|c|c||}
\hline \multicolumn{3}{|c|}{ Composite Materials } & \multicolumn{7}{c||}{$\begin{array}{c}\text { Flux Level } \\
\left(\mathrm{kW} / \mathrm{m}^{2}\right)\end{array}$} \\
\hline Fabric & Foam & Interbarrier & 25 & $\begin{array}{c}\text { CV } \\
\%\end{array}$ & 35 & $\begin{array}{c}\text { CV } \\
\%\end{array}$ & 50 & $\begin{array}{c}\text { CV } \\
\%\end{array}$ \\
\hline Nylon & Polyurethane & No & 390 & 1 & 390 & 2 & 400 & 1 \\
\hline Nylon & Melamine & No & $205^{*}$ & 1 & 270 & 3 & 315 & 7 \\
\hline Nylon & Melamine & Yes & 205 & 7 & 255 & 3 & 345 & 1 \\
\hline Polyolefin & Polyurethane & No & 340 & 4 & 355 & 1 & 355 & 0.4 \\
\hline Polyolefin & Melamine & No & 165 & 10 & 210 & 10 & 285 & 3 \\
\hline Polyolefin & Melamine & Yes & 235 & 7 & 205 & 4 & 265 & 3 \\
\hline PVC & Polyurethane & No & 180 & 5 & 235 & 6 & 335 & 3 \\
\hline PVC & Melamine & No & 150 & 2 & 185 & 5 & 230 & 6 \\
\hline PVC & Melamine & Yes & 140 & 4 & 160 & 11 & 220 & 6 \\
\hline- & Polyurethane & No & $240^{*}$ & - & $240^{*}$ & - & $240^{*}$ & - \\
\hline- & Melamine & No & NI* & - & $105^{*}$ & - & $140^{*}$ & - \\
\hline
\end{tabular}

* - Single Determination

NI - No Ignition

$(-)$ - Coefficient of variation could not be determined. 
Table 6. Peak Rate of Heat Release

$\left(\mathrm{kW} / \mathrm{m}^{2}\right)$

\begin{tabular}{||c|c|c|c|c|c|c|c|c||}
\hline \multicolumn{3}{|c|}{ Composite Materials } & \multicolumn{7}{c|}{$\begin{array}{c}\text { Flux Level } \\
\left(\mathrm{kW} / \mathrm{m}^{2}\right)\end{array}$} \\
\hline Fabric & Foam & Interbarrier & 25 & $\begin{array}{c}\text { CV } \\
\%\end{array}$ & 35 & $\begin{array}{c}\text { CV } \\
\%\end{array}$ & 50 & $\begin{array}{c}\text { CV } \\
\%\end{array}$ \\
\hline Nylon & Polyurethane & No & 505 & 8 & 640 & 2 & 640 & 12 \\
\hline Nylon & Melamine & No & $350^{*}$ & - & 370 & 8 & 420 & 8 \\
\hline Nylon & Melamine & Yes & 285 & 8 & 370 & 3 & 505 & 6 \\
\hline Polyolefin & Polyurethane & No & 540 & 2 & 770 & 11 & 890 & 1 \\
\hline Polyolefin & Melamine & No & 240 & 4 & 310 & 6 & 415 & 20 \\
\hline Polyolefin & Melamine & Yes & 310 & 9 & 340 & 16 & 450 & 0.2 \\
\hline PVC & Polyurethane & No & 290 & 6 & 525 & 24 & 560 & 20 \\
\hline PVC & Melamine & No & 345 & 4 & 345 & 6 & 365 & 2 \\
\hline PVC & Melamine & Yes & 275 & 4 & 295 & 2 & 370 & 6 \\
\hline- & Polyurethane & No & $425^{*}$ & - & $595^{*}$ & - & $785^{*}$ & - \\
\hline- & Melamine & No & NI* & - & $180^{*}$ & - & $230^{*}$ & - \\
\hline
\end{tabular}

* - Single Determination

NI - No Ignition

$(-)$ - Coefficient of variation could not be determined. 
Table 7. 120 Second Interval Rate of Heat Release

$\left(\mathbf{k W} / \mathrm{m}^{2}\right)$

\begin{tabular}{|c|c|c|c|c|c|c|c|c|}
\hline \multicolumn{3}{|c|}{ Composite Materials } & \multicolumn{6}{|c|}{$\begin{array}{l}\text { Flux Level } \\
\left(\mathrm{kW} / \mathrm{m}^{2}\right)\end{array}$} \\
\hline Fabric & Foam & Interbarrier & 25 & $\begin{array}{c}\mathrm{CV} \\
\%\end{array}$ & 35 & $\begin{array}{c}\mathrm{CV} \\
\%\end{array}$ & 50 & $\begin{array}{l}\mathrm{CV} \\
\%\end{array}$ \\
\hline Nylon & Polyurethane & No & 370 & 2 & 455 & 5 & 565 & 0.5 \\
\hline Nylon & Melamine & No & $155^{*}$ & - & 255 & 8 & 205 & 9 \\
\hline Nylon & Melamine & Yes & 200 & 3 & 280 & 1 & 350 & 3 \\
\hline Polyolefin & Polyurethane & No & 365 & 5 & 465 & 2 & 525 & 0.3 \\
\hline Polyolefin & Melamine & No & 175 & 2 & 205 & 8 & 250 & 19 \\
\hline Polyolefin & Melamine & Yes & 240 & 8 & 230 & 3 & 275 & 5 \\
\hline PVC & Polyurethane & No & 175 & 9 & 200 & 4 & 300 & 5 \\
\hline PVC & Melamine & No & 155 & 2 & 185 & 3 & 235 & 3 \\
\hline PVC & Melamine & Yes & 145 & 4 & 175 & 9 & 200 & 7 \\
\hline- & Polyurethane & No & $310^{*}$ & - & $375^{*}$ & - & $355^{*}$ & - \\
\hline - & Melamine & No & $\mathrm{NI}^{*}$ & - & $95^{*}$ & - & $125^{*}$ & - \\
\hline
\end{tabular}

* - Single Determination

NI - No Ignition

$(-)$ - Coefficient of variation could not be determined. 
Table 8. 15 Second Interval Rate of Heat Release

$$
\left(\mathrm{kW} / \mathrm{m}^{2}\right)
$$

\begin{tabular}{||c|c|c|c|c|c|c|c|c||}
\hline \multicolumn{3}{|c|}{ Composite Materials } & \multicolumn{7}{c|}{$\begin{array}{c}\text { Flux Level } \\
\left(\mathrm{kW} / \mathrm{m}^{2}\right)\end{array}$} \\
\hline Fabric & Foam & Interbarrier & 25 & $\begin{array}{c}\text { CV } \\
\%\end{array}$ & 35 & $\begin{array}{c}\text { CV } \\
\%\end{array}$ & 50 & $\begin{array}{c}\text { CV } \\
\%\end{array}$ \\
\hline Nylon & Polyurethane & No & 220 & 0.3 & 205 & 33 & 295 & 31 \\
\hline Nylon & Melamine & No & $25^{*}$ & - & 165 & 10 & 205 & 16 \\
\hline Nylon & Melamine & Yes & 50 & 52 & 245 & 5 & 230 & 4 \\
\hline Polyolefin & Polyurethane & No & 140 & 24 & 185 & 41 & 235 & 7 \\
\hline Polyolefin & Melamine & No & 120 & 5 & 135 & 36 & 185 & 34 \\
\hline Polyolefin & Melamine & Yes & 50 & 11 & 85 & 36 & 170 & 52 \\
\hline PVC & Polyurethane & No & 175 & 8 & 230 & - & 300 & 23 \\
\hline PVC & Melamine & No & 180 & 24 & 240 & 3 & 240 & 3 \\
\hline PVC & Melamine & Yes & 160 & 10 & 245 & 8 & 270 & 18 \\
\hline- & Polyurethane & No & $110^{*}$ & - & $180^{*}$ & - & $225^{*}$ & - \\
\hline- & Melamine & No & NI* & - & $25^{*}$ & - & $120^{*}$ & - \\
\hline
\end{tabular}

* - Single Determination

NI - No Ignition

$(-)$ - Coefficient of variation could not be determined. 
Table 9. Production of Carbon Monoxide

$$
\left(\mathrm{kg} \mathrm{CO} / \mathrm{m}^{2}\right)
$$

\begin{tabular}{||c|c|c|c|c|c|c|c|c||}
\hline \multicolumn{3}{|c|}{ Composite Materials } & \multicolumn{6}{c||}{$\begin{array}{c}\text { Flux Level } \\
\left(\mathrm{kW} / \mathrm{m}^{2}\right)\end{array}$} \\
\hline Fabric & Foam & Interbarrier & 25 & $\begin{array}{c}\text { CV } \\
\%\end{array}$ & 35 & $\begin{array}{c}\text { CV } \\
\%\end{array}$ & 50 & $\begin{array}{c}\text { CV } \\
\%\end{array}$ \\
\hline Nylon & Polyurethane & No & .046 & 8 & .049 & 8 & .050 & 3 \\
\hline Nylon & Melamine & No & $.035^{*}$ & 2 & .044 & 10 & .053 & 2 \\
\hline Nylon & Melamine & Yes & .064 & 5 & .059 & 4 & .092 & 4 \\
\hline Polyolefin & Polyurethane & No & .040 & 6 & .051 & 2 & .052 & 3 \\
\hline Polyolefin & Melamine & No & .040 & 2 & .043 & 13 & .050 & 14 \\
\hline Polyolefin & Melamine & Yes & .072 & 1 & .071 & 2 & .074 & 1 \\
\hline PVC & Polyurethane & No & .299 & 4 & .305 & 1 & .306 & 4 \\
\hline PVC & Melamine & No & .261 & 1 & .267 & 1 & .262 & 1 \\
\hline PVC & Melamine & Yes & .293 & 1 & .275 & 12 & .275 & 14 \\
\hline- & Polyurethane & No & $.024^{*}$ & - & $.025^{*}$ & - & $.027 *$ & - \\
\hline- & Melamine & No & NI* & - & $.019 *$ & - & $.020^{*}$ & - \\
\hline
\end{tabular}

* - Single Determination

NI - No Ignition

$(-)$ - Coefficient of variation could not be determined.

Yield Calculation:

$\frac{\text { CO Produced }(\mathrm{kg})}{\text { Unit of Material }(\mathrm{kg})} \times \frac{\text { Mass of Sample Consumed }(\mathrm{g})}{\text { Area of Sample }\left(\mathrm{m}^{2}\right)} \times \frac{\mathrm{kg}}{1000 \mathrm{~g}}=\frac{\mathrm{kg}}{\mathrm{m}^{2}}$ 
Table 10. Yield of Carbon Dioxide

( $\mathrm{kg} \mathrm{CO} / 2 / \mathrm{kg}$ of sample)

\begin{tabular}{||c|c|c|c|c|c|c|c|c||}
\hline \multicolumn{3}{|c|}{ Composite Materials } & \multicolumn{7}{c||}{$\begin{array}{c}\text { Flux Level } \\
\left(\mathrm{kW} / \mathrm{m}^{2}\right)\end{array}$} \\
\hline Fabric & Foam & Interbarrier & 25 & $\begin{array}{c}\text { CV } \\
\%\end{array}$ & 35 & $\begin{array}{c}\text { CV } \\
\%\end{array}$ & 50 & $\begin{array}{c}\text { CV } \\
\%\end{array}$ \\
\hline Nylon & Polyurethane & No & 1.9 & 1 & 1.9 & 1 & 2.0 & 4 \\
\hline Nylon & Melamine & No & $1.5 *$ & 1 & 1.5 & 4 & 1.6 & 4 \\
\hline Nylon & Melamine & Yes & 1.6 & 0.9 & 1.5 & 2 & 1.6 & 2 \\
\hline Polyolefin & Polyurethane & No & 2.1 & 1 & 2.0 & 0.3 & 2.2 & 4 \\
\hline Polyolefin & Melamine & No & 1.6 & 1 & 1.5 & 2 & 1.6 & 4 \\
\hline Polyolefin & Melamine & Yes & 1.5 & 1 & 1.5 & 1 & 1.6 & 1 \\
\hline PVC & Polyurethane & No & 1.2 & 4 & 1.2 & 0 & 1.1 & 2 \\
\hline PVC & Melamine & No & 1.1 & 2 & 1.1 & 2 & 1.1 & 4 \\
\hline PVC & Melamine & Yes & 1.1 & 4 & 1.1 & 4 & 0.9 & 20 \\
\hline- & Polyurethane & No & $1.9^{*}$ & - & $1.9^{*}$ & - & $1.9^{*}$ & - \\
\hline- & Melamine & No & NI* & - & $1.4^{*}$ & - & $1.2^{*}$ & - \\
\hline
\end{tabular}

* - Single Determination

NI - No Ignition

$(-)$ - Coefficient of variation could not be determined. 
Table 11. Yield of Water

(kg $\mathrm{H}_{2} \mathrm{O} / \mathrm{kg}$ of sample)

\begin{tabular}{||c|c|c|c|c|c|c|c|c||}
\hline \multicolumn{3}{|c|}{ Composite Materials } & \multicolumn{7}{c|}{$\begin{array}{c}\text { Flux Level } \\
\left(\mathrm{kW} / \mathrm{m}^{2}\right)\end{array}$} \\
\hline Fabric & Foam & Interbarrier & 25 & $\begin{array}{c}\text { CV } \\
\%\end{array}$ & 35 & $\begin{array}{c}\text { CV } \\
\%\end{array}$ & 50 & $\begin{array}{c}\text { CV } \\
\%\end{array}$ \\
\hline Nylon & Polyurethane & No & .78 & 3 & .76 & .5 & .77 & 2 \\
\hline Nylon & Melamine & No & $.78^{*}$ & - & .67 & 1 & .71 & 6 \\
\hline Nylon & Melamine & Yes & .67 & 6 & .62 & 9 & .69 & 6 \\
\hline Polyolefin & Polyurethane & No & .69 & 0.2 & .82 & 1 & .92 & 1 \\
\hline Polyolefin & Melamine & No & .80 & 1 & .74 & 5 & .80 & 11 \\
\hline Polyolefin & Melamine & Yes & .69 & 3 & .65 & - & .76 & 12 \\
\hline PVC & Polyurethane & No & .59 & 6 & .56 & 5 & .54 & 6 \\
\hline PVC & Melamine & No & .57 & 1 & .53 & 2 & .58 & 2 \\
\hline PVC & Melamine & Yes & .52 & 21 & .52 & 5 & .92 & 21 \\
\hline- & Polyurethane & No & $.73^{*}$ & - & $.72^{*}$ & - & $.71^{*}$ & - \\
\hline- & Melamine & No & NI* & - & $.88^{*}$ & - & $.61^{*}$ & - \\
\hline \hline
\end{tabular}

\section{* - Single Determination}

NI - No Ignition

$(-)$ - Coefficient of variation could not be determined. 
Table 12. Yield of Total Unburned Hydrocarbons

(kg TUH/kg of sample)

\begin{tabular}{||c|c|c|c|c|c|c|c|c||}
\hline \multicolumn{3}{|c|}{ Composite Materials } & \multicolumn{7}{c||}{$\begin{array}{c}\text { Flux Level } \\
\left(\mathrm{kW} / \mathrm{m}^{2}\right)\end{array}$} \\
\hline Fabric & Foam & Interbarrier & 25 & $\begin{array}{c}\text { CV } \\
\%\end{array}$ & 35 & $\begin{array}{c}\text { CV } \\
\%\end{array}$ & 50 & $\begin{array}{c}\text { CV } \\
\%\end{array}$ \\
\hline Nylon & Polyurethane & No & .003 & 7 & .003 & 2 & .003 & 17 \\
\hline Nylon & Melamine & No & $.011^{*}$ & 4 & .008 & 24 & .003 & 15 \\
\hline Nylon & Melamine & Yes & .011 & 11 & .008 & 2 & .007 & 2 \\
\hline Polyolefin & Polyurethane & No & .004 & 39 & .004 & 5 & .004 & 4 \\
\hline Polyolefin & Melamine & No & .004 & 9 & .004 & 4 & .004 & 17 \\
\hline Polyolefin & Melamine & Yes & .008 & 11 & .008 & 8 & .008 & 14 \\
\hline PVC & Polyurethane & No & .027 & 7 & .029 & 3 & .031 & 4 \\
\hline PVC & Melamine & No & .022 & 9 & .018 & 9 & .022 & 2 \\
\hline PVC & Melamine & Yes & .024 & 15 & .022 & 8 & .023 & 26 \\
\hline- & Polyurethane & No & $.002^{*}$ & - & $.003^{*}$ & - & $.003 *$ & - \\
\hline- & Melamine & No & NI* & - & $.013^{*}$ & - & $.003^{*}$ & - \\
\hline
\end{tabular}

* - Single Determination

NI - No Ignition

$(-)$ - Coefficient of variation could not be determined. 
Table 13. Production of Smoke

$$
\left(\mathrm{m}^{2} / \mathrm{m}^{2}\right)
$$

\begin{tabular}{||c|c|c|c|c|c|c|c|c||}
\hline \multicolumn{3}{|c|}{ Composite Materials } & \multicolumn{5}{c|}{$\begin{array}{c}\text { Flux Level } \\
\left(\mathrm{kW} / \mathrm{m}^{2}\right)\end{array}$} \\
\hline Fabric & Foam & Interbarrier & 25 & $\begin{array}{c}\text { CV } \\
\%\end{array}$ & 35 & $\begin{array}{c}\text { CV } \\
\%\end{array}$ & 50 & $\begin{array}{c}\text { CV } \\
\%\end{array}$ \\
\hline Nylon & Polyurethane & No & 850 & 1 & 820 & 1 & 760 & 6 \\
\hline Nylon & Melamine & No & $610^{*}$ & 1 & 750 & 7 & 760 & 4 \\
\hline Nylon & Melamine & Yes & 1080 & 7 & 1180 & 1 & 1180 & 12 \\
\hline Polyolefin & Polyurethane & No & 720 & 3 & 710 & 3 & 670 & 0.3 \\
\hline Polyolefin & Melamine & No & 590 & 8 & 710 & 2 & 750 & 3 \\
\hline Polyolefin & Melamine & Yes & 1070 & 8 & 1120 & 0.1 & 1000 & 4 \\
\hline PVC & Polyurethane & No & 2320 & 1 & 2390 & 1 & 2440 & 0.5 \\
\hline PVC & Melamine & No & 1660 & 1 & 1980 & 1 & 2140 & 3 \\
\hline PVC & Melamine & Yes & 1700 & 1 & 2070 & 12 & 2670 & 8 \\
\hline- & Polyurethane & No & $380^{*}$ & - & $390^{*}$ & - & $370^{*}$ & - \\
\hline- & Melamine & No & NI* & - & $160^{*}$ & - & $300^{*}$ & - \\
\hline
\end{tabular}

* - Single Determination

NI - No Ignition

$(-)$ - Coefficient of variation could not be determined.

Yield Calculation:

$\frac{\text { Extinction area }\left(\mathrm{m}^{2}\right)}{\text { Unit of Material }(\mathrm{kg})} \times \frac{\text { Mass of Sample Consumed }(\mathrm{g})}{\text { Area of Sample }(\mathrm{m})} \times \frac{\mathrm{kg}}{1000 \mathrm{~g}}=\frac{\mathrm{m}^{2}}{\mathrm{~m}^{2}}$ 


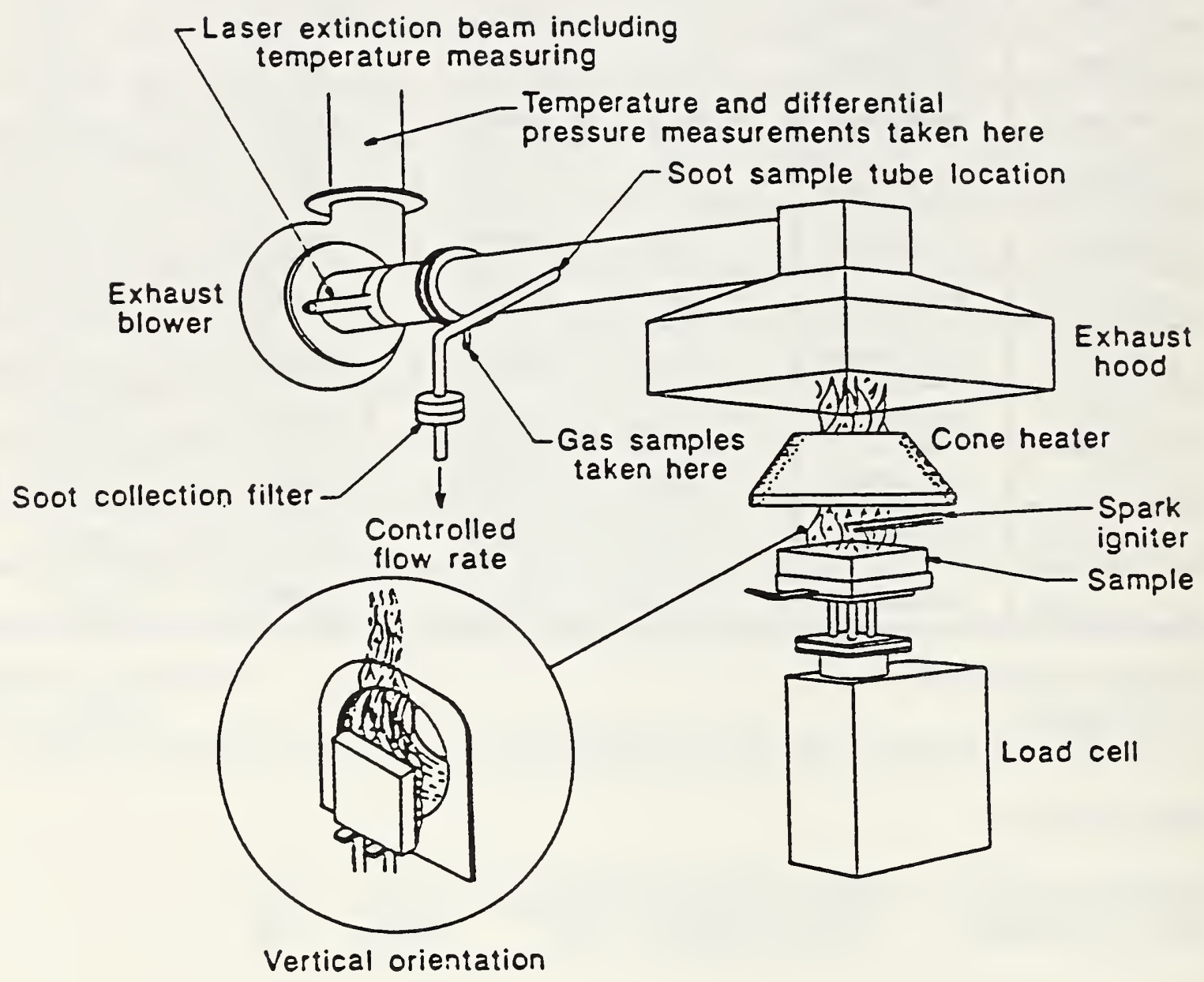

Figure 1. Schematic Diagram of the Cone Calorimeter. 


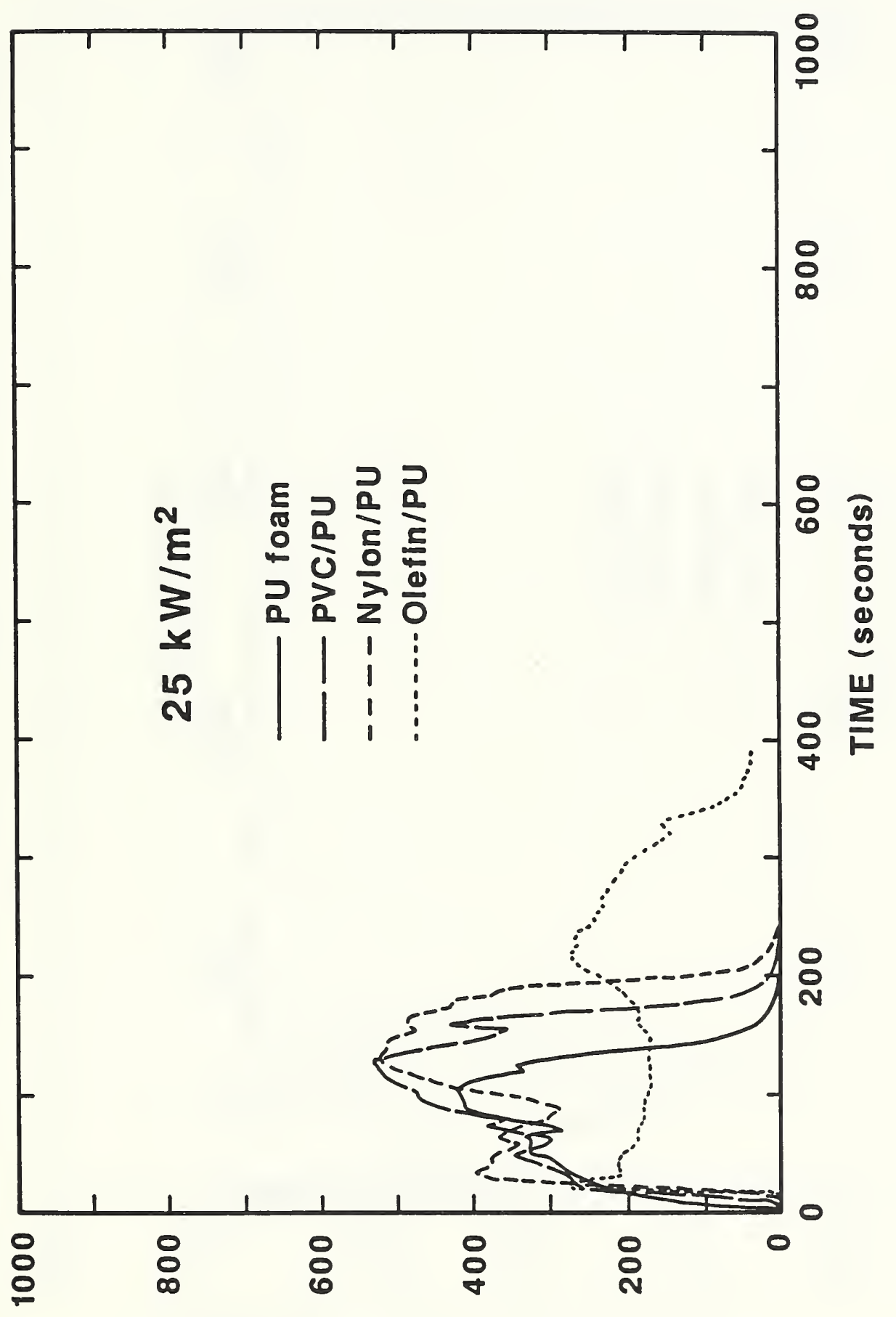

告 


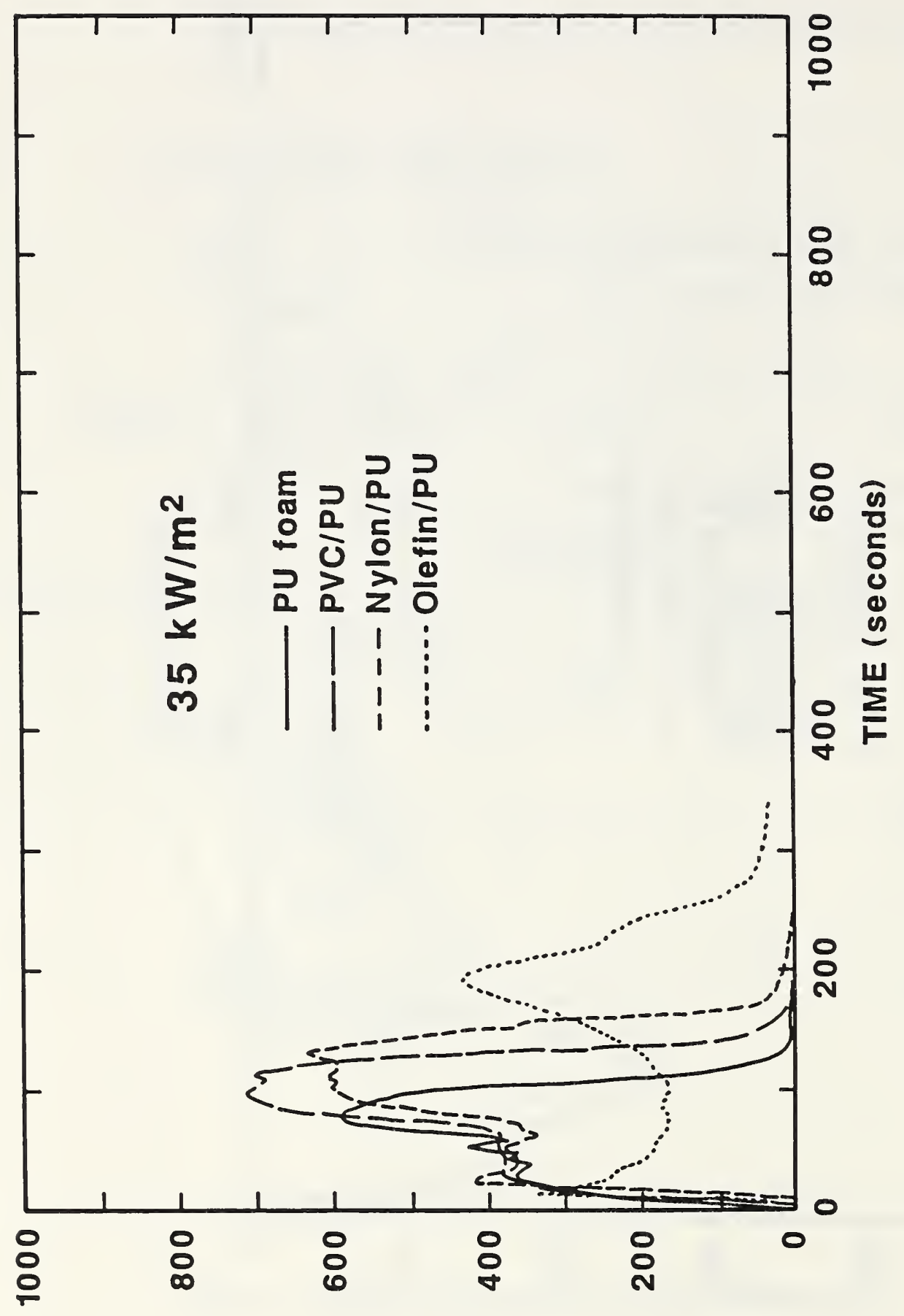

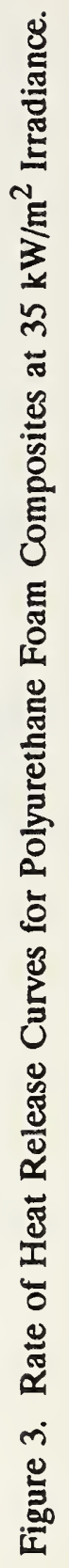




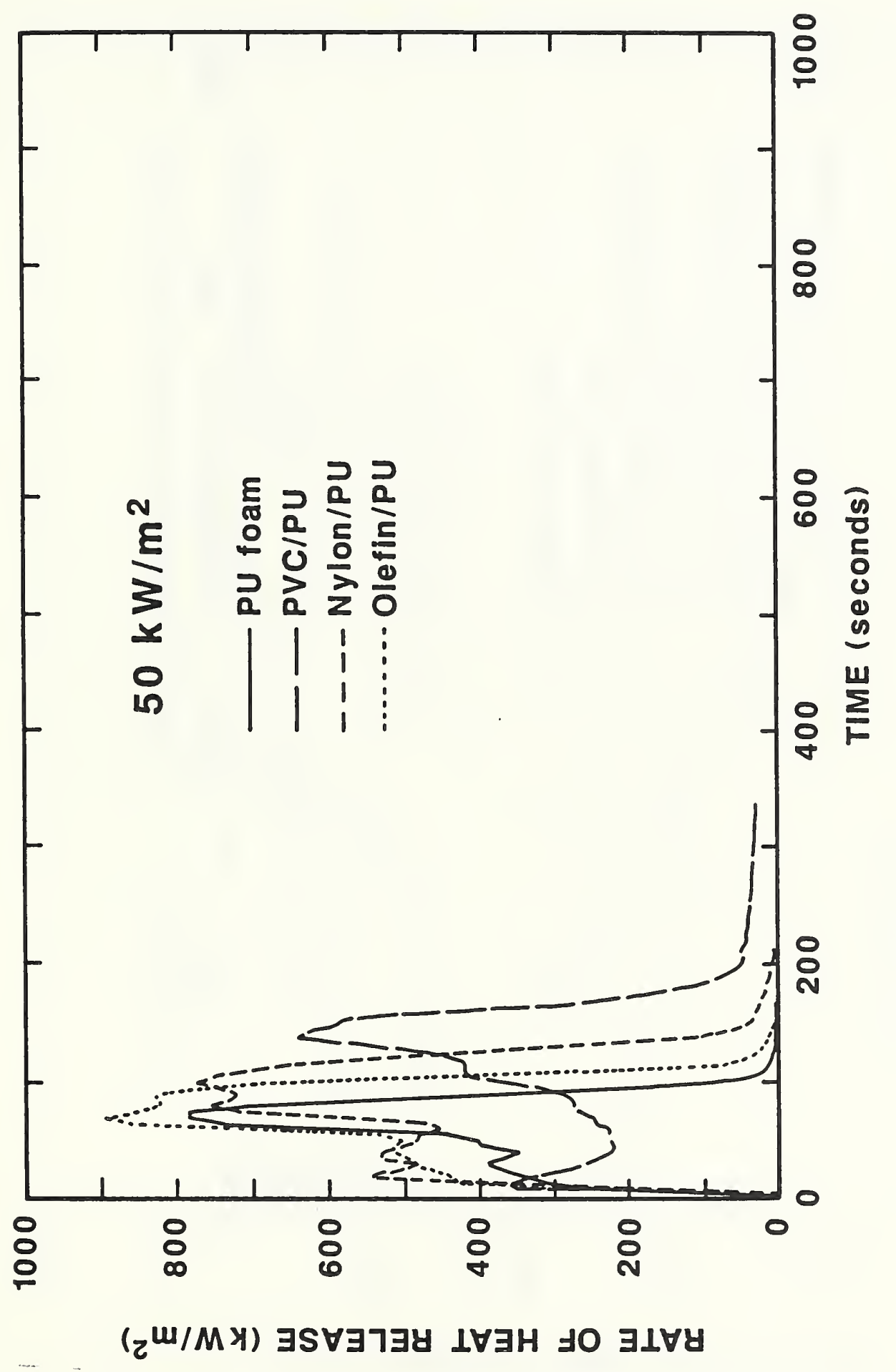

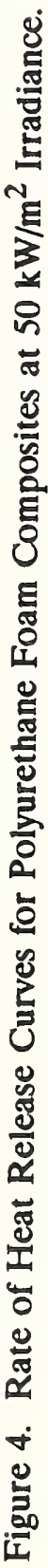




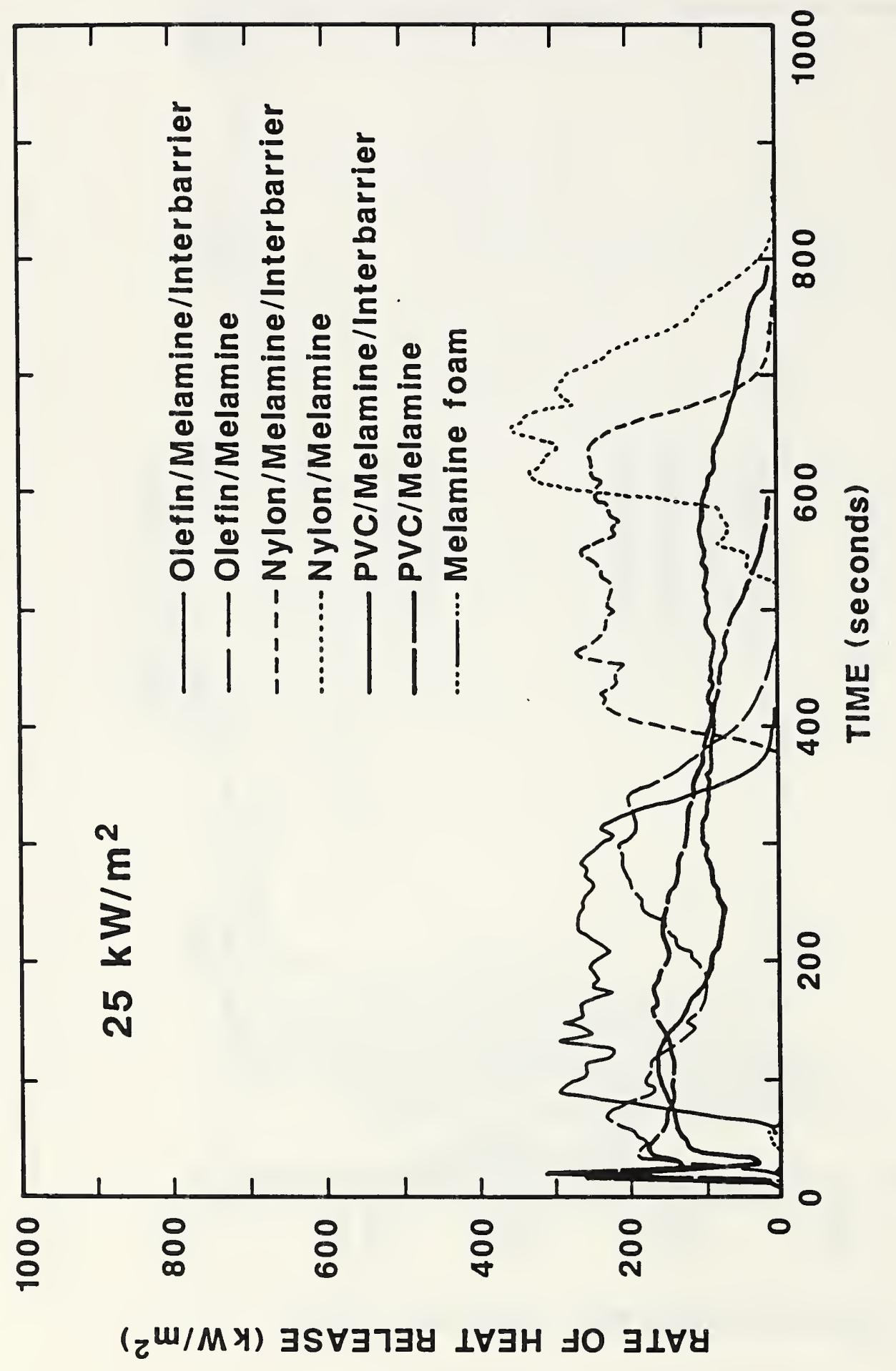

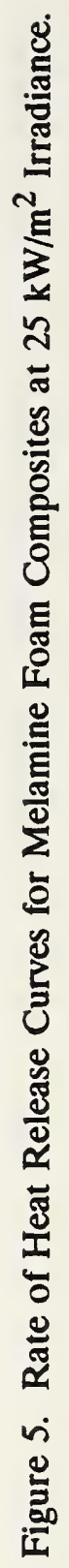




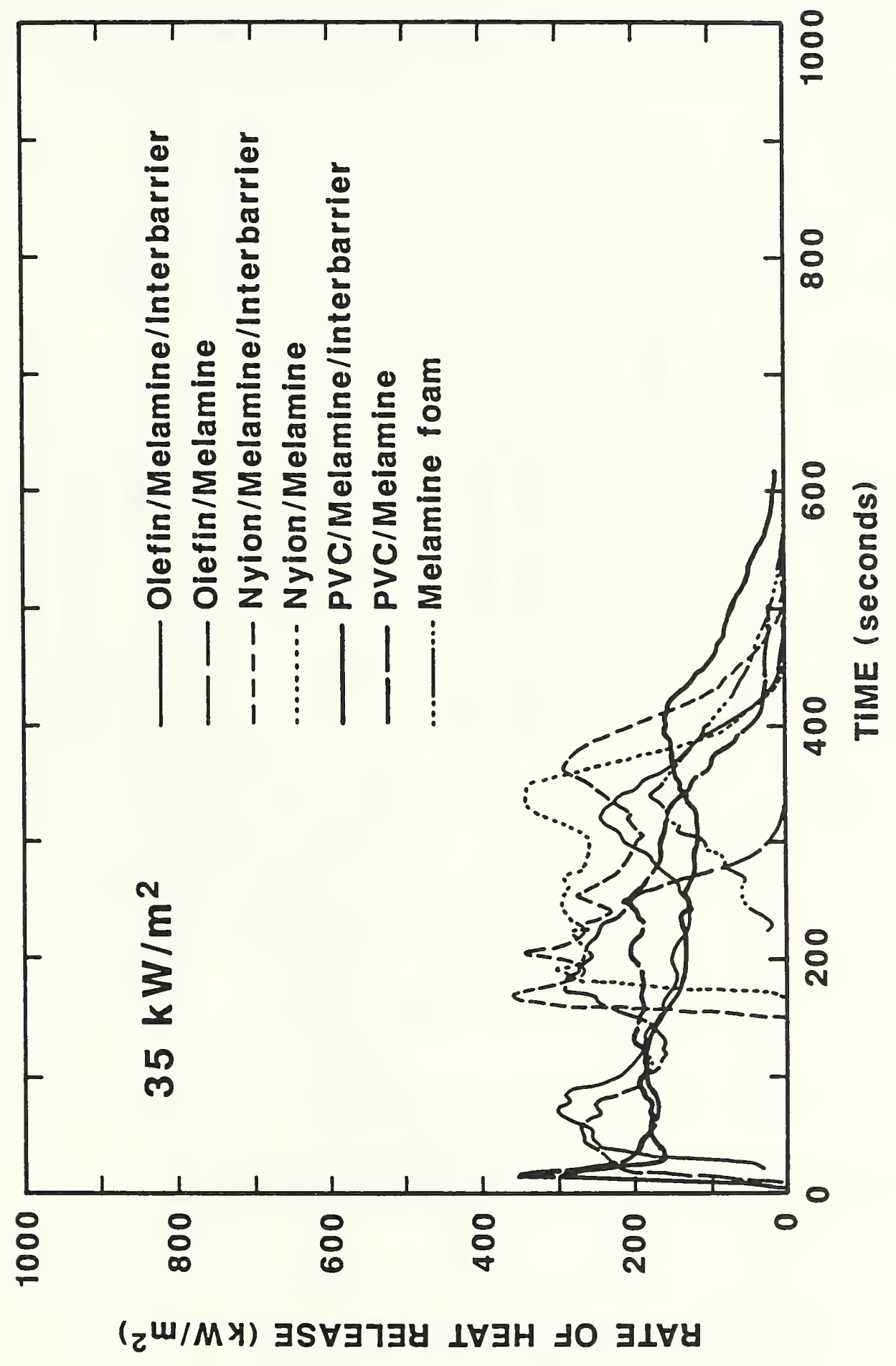

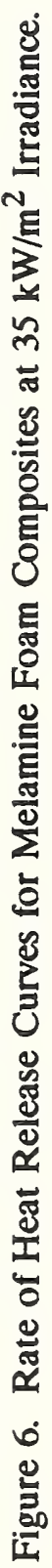




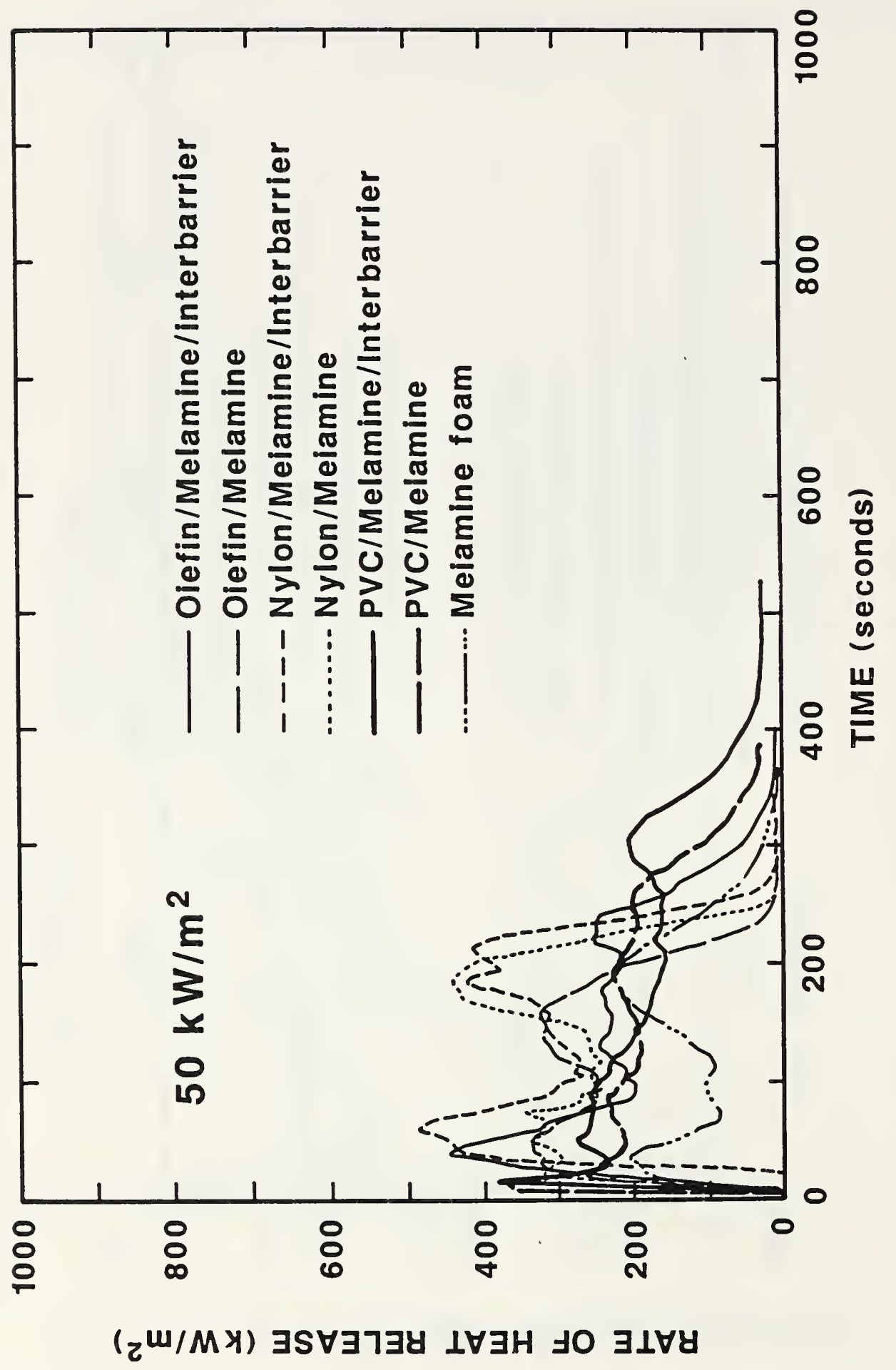

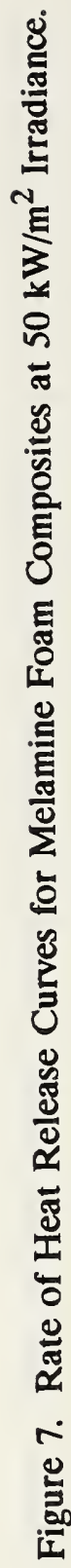




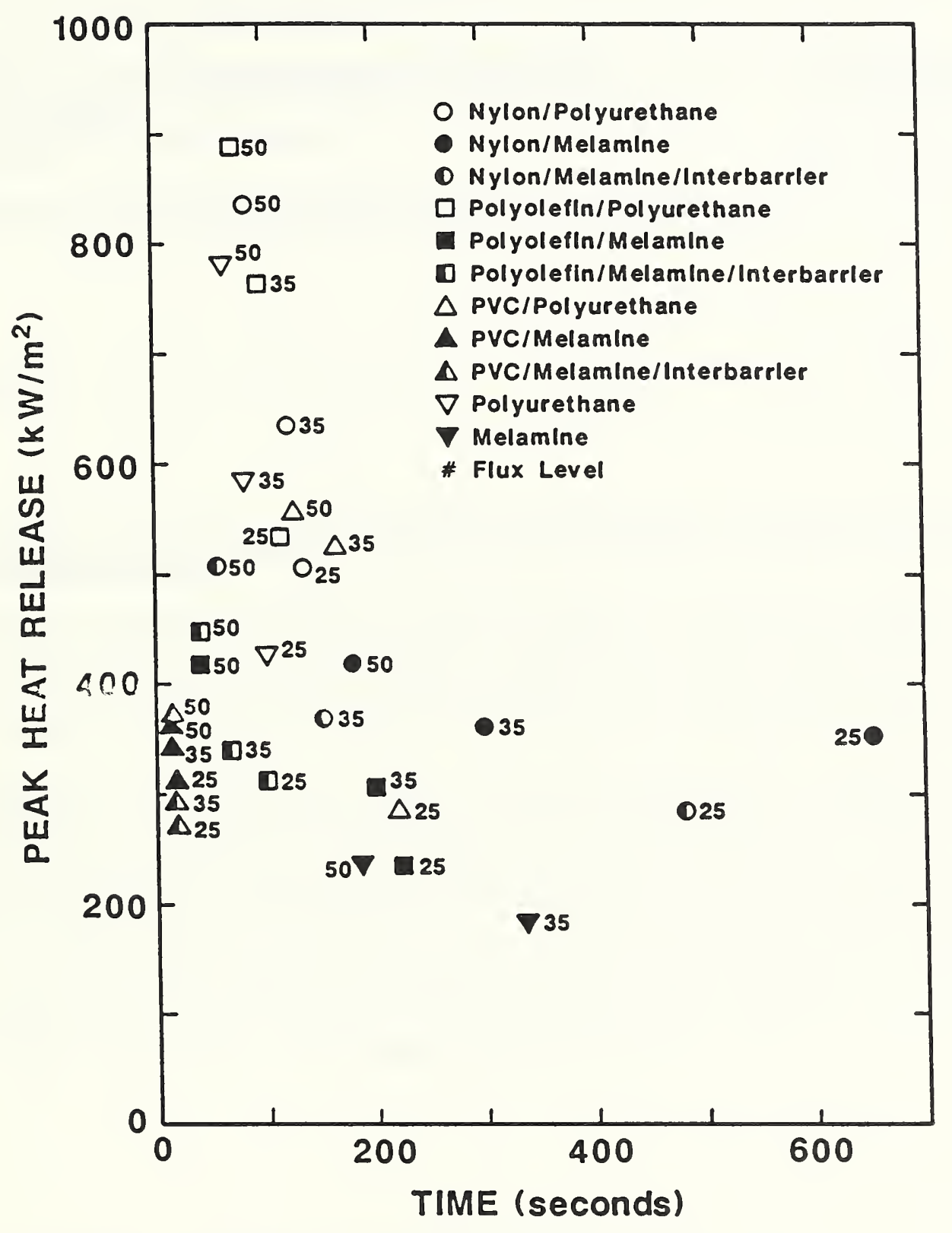

Figure 8. Peak Heat Release versus Time of Peak for 3 Flux Levels $\left(25,35,50 \mathrm{~kW} / \mathrm{m}^{2}\right)$. 

NIST-114A

(REV. 3-90)
U.S. DEPARTMENT OF COMMERCE NATIONAL INSTITUTE OF STANDARDS AND TECHNOLOGY

\section{BIBLIOGRAPHIC DATA SHEET}

1. PUBUCATION OR REPORT MUMBER NISTIR 4652

2. PERFOAMINQ OAQANIZATION AEPOAT MUMBEA

3. PUBucation date

August 1991

\section{TITLE AND SUBTITLE}

Cone Calorimeter Rate of Heat Release Measurements for Upholstered Composites of Polyurethane Foams

5. AUTHOR(S)

Kay M. Villa and Vytenis Babrauskas

6. PEAFormina ORGanization (IF JOINT OR OTHER THAN MIST, SEE INSTAUCTIONS)

U.S. DEPAATMENT OF COMMEACE

NATIONAL INSTITUTE OF STANDARDS AND TECHNOLOQY

GATHER SBURG, MD 20090

7. CONTRACT/GRANT MUMBER

O. TYPE OF REPOAT ANO PERIOD COVEAED

9. SPONSORIMO ORQANIZATION MAME AND COMPLETE ADDRESS (STAEET, CITY, STATE, ZIP)

11. ABSTRACT (A 2OO-WOAD OA LESS FACTUAL SUMMARY OF MOST SIGMIFICANT INFORMATION. IF DOCUMENT INCLUDES A SIONIFICANT BIBUOQRAPHY OR UTERATURE SURVEY, MENTION IT MERE.)

Certain regulatory authorities have recently banned or restricted the use of furniture upholstered with a combination of polyvinyl chloride (PVC) covering and a melamine-treated polyurethane foam padding. Thus, it was endeavored to determine if quantitative measurements would reveal any special hazards associated with this particular combination.

The work represents the testing of nine different upholstered composites, made of fabric coverings and polyurethane foam, tested at three different irradiance levels in the National Institute of Standards and Technology Cone Calorimeter. Additional combinations using a polyester batting interbarrier were also used. The composite bench-scale specimens were tested at $25 \mathrm{~kW} / \mathrm{sq} \cdot \mathrm{m}, 35 \mathrm{~kW} / \mathrm{sq} \cdot \mathrm{m}$ and $50 \mathrm{~kW} / \mathrm{sq} \cdot \mathrm{m}$ irradiance levels. For most variables describing fire hazard, the performance of the combination of melamine-treated polyurethane foam and PVC fabric covering was not found to behave in an unusual manner. Only by considering the time period of 15 seconds after ignition was this combination numerically worse than all other combinations tested.

12. KEY WOADS (6 TO 12 ENTAIES; ALPHABETICAL OADER; CAPITALIZE ONLY PROPER MAMES; AND SEPARATE KEY WORDS BY SEMICOLONS) composite materials; Cone Calorimeters; heat release rate; melamine; nylon (trademark); polyolefins; polyurethane foam; polyvinyl chloride; upholstered furniture.

\section{AVAILABIUTY}

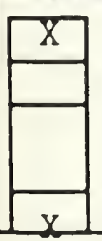

UNUMITED

FOR OFFICIAL DISTRIBUTION. DO NOT RELEASE TO HATIONAL TECHNICAL INFORMATION SEAVICE (NTIS).

ORDER FROM SUPERINTENDENT OF DOCUMENTS, U.S. GOVERNMENT PRINTIMQ OFFICE, WASHINOTON, DC 20402.

ORDER FAOM MATIONAL TECHMICAL INFORMATION SERVICE (NTIS), SPAINOFIELD, VA 22161.
14. NUMBER OF PAINTED PAQES

$$
39
$$

15. PAICE

А03 

